Article

\title{
Expanding the Repertoire of Spongian-16-One Derivatives in Australian Nudibranchs of the Genus Goniobranchus and Evaluation of Their Anatomical Distribution
}

\author{
Louise C. Forster ${ }^{1}$, Jack K. Clegg ${ }^{1}$, Karen L. Cheney ${ }^{2}$ (I) and Mary J. Garson ${ }^{1, *(\mathbb{D})}$ \\ 1 School of Chemistry and Molecular Biosciences, The University of Queensland, \\ St. Lucia, QLD 4072, Australia; 1.forster1@uq.edu.au (L.C.F.); j.clegg@uq.edu.au (J.K.C.) \\ 2 School of Biological Sciences, The University of Queensland, St. Lucia, QLD 4072, Australia; \\ k.cheney@uq.edu.au \\ * Correspondence: m.garson@uq.edu.au; Tel.: +61-733653605
}

check for updates

Citation: Forster, L.C.; Clegg, J.K.; Cheney, K.L.; Garson, M.J. Expanding the Repertoire of Spongian-16-One Derivatives in Australian

Nudibranchs of the Genus Goniobranchus and Evaluation of Their Anatomical Distribution. Mar. Drugs 2021, 19, 680. https://doi.org/ $10.3390 /$ md19120680

Academic Editors: Angelo Fontana and Margherita Gavagnin

Received: 25 October 2021

Accepted: 25 November 2021

Published: 29 November 2021

Publisher's Note: MDPI stays neutral with regard to jurisdictional claims in published maps and institutional affiliations.

Copyright: (c) 2021 by the authors. Licensee MDPI, Basel, Switzerland. This article is an open access article distributed under the terms and conditions of the Creative Commons Attribution (CC BY) license (https:// creativecommons.org/licenses/by/ $4.0 /)$.

\begin{abstract}
Extracts of the mantle and viscera of the Indo-Pacific nudibranchs Goniobranchus aureopurpureus and Goniobranchus sp. 1 afforded 11 new diterpenoids (1-11), all of which possess a tetracyclic spongian-16-one scaffold with extensive oxidation at C-6, C-7, C-11, C-12, C-13, and/or $\mathrm{C}-20$. The structures and relative configuration were investigated by NMR experiments, while $X$-ray crystallography provided the absolute configuration of $\mathbf{1}$, including a 2 ' $S$ configuration for the 2methylbutanoate substituent located at C-7. Dissection of animal tissue revealed that the mantle and viscera tissues differed in their metabolite composition with diterpenes 1-11 present in the mantle tissue of the two nudibranch species.
\end{abstract}

Keywords: diterpenes; nudibranch; Chromodorididae; Goniobranchus aureopurpureus; X-ray crystallography

\section{Introduction}

Spongian diterpenes are bioactive natural products isolated from sponges of the orders Dictyoceratida and Dendroceratida, and nudibranchs (shell-less mollusc) predators [1,2]. The first example of the spongian diterpene scaffold was isoagatholactone, isolated from the Mediterranean sponge Spongia officinalis by Cimino et al., and with the structure and absolute configuration established through chemical correlation with grindelic acid [3]. The metabolites spongian-16-one and spongian-15,16-dione were isolated from the New Zealand sponge Dictyodendrilla cavernosa [4]. The structure of spongian-16-one was determined through exhaustive nuclear magnetic resonance (NMR) studies carried out independently by two groups, those of Kernan et al. [4] and Hambley et al. [5]. Spongian-16-one has also been isolated from several nudibranch species, including Chromodoris obsoleta and exhibits moderate anti-neoplastic activity against $\mathrm{L} 1210\left(\mathrm{IC}_{50}=5.0 \mu \mathrm{g} \mathrm{mL}{ }^{-1}\right)$ and $\mathrm{KB}$ $\left(\mathrm{IC}_{50}=9.2 \mu \mathrm{g} \mathrm{mL}^{-1}\right)$ cell lines [6]. In this group of tetracyclic diterpenes, further oxidation is commonly seen at C-7, C-11, C-12, C-13, C-15, C-17, and/or C-20 [7].

The current study, which forms part of our comprehensive study on nudibranchs of the genus Goniobranchus [7-19], represents the first chemical report on the secondary metabolite profile of the two nudibranch species, Goniobranchus aureopurpureus and Goniobranchus sp. 1 [20], each reassigned from an earlier taxonomic classification as Chromodoris species [21]. The structures and relative configuration of eleven isolated diterpene metabolites were determined by analysis of their two-dimensional NMR spectra as well as where applicable by X-ray crystallography to determine the absolute configuration. Our study also investigated the anatomical location of the terpenes and compared this with the distribution of metabolites in other Goniobranchus species. 


\section{Results and Discussions}

\subsection{Diterpenes from Goniobranchus aureopurpureus}

Six specimens of G. aureopurpureus were collected from Nelson Bay (New South Wales, Australia) in March 2016. Specimens were dissected into their mantle and viscera and each body part was finely chopped, extracted with acetone and the extract concentrated under vacuum. The aqueous residues were partitioned with diethyl ether to yield an orange oil from the mantles and a green oil from the visceras. The individual mantle extracts were combined, as were the individual viscera extracts prior to fractionation by silica-flash chromatography. Subsequent normal phase high-performance liquid chromatography (NPHPLC) yielded terpenes 1-5. The known compounds macfarlandin E [22], aplyviolene [23], polyrhaphin B [24], shahamin C [25], and secoshahamin [26] were also isolated from the mantle extract, while the viscera provided luffarin-X [27], spongian-16-one [4,5], $7 \alpha$ acetoxyspongian-16-one [28], polyrhaphin A [24], 15,16-diacetoxyshahamin B [25], and 12desacetoxypolyrhaphin A [29]. The known terpenes spongian-16-one, $7 \alpha$-acetoxyspongian16-one, macfarlandin E, aplyviolene, polyrhaphin B, and secoshahamin were isolated from both tissues. The new spongian diterpenes (1-5) show varying levels of oxidation, particularly at positions C-6, C-7, C-13 and C-20 (Figure 1).
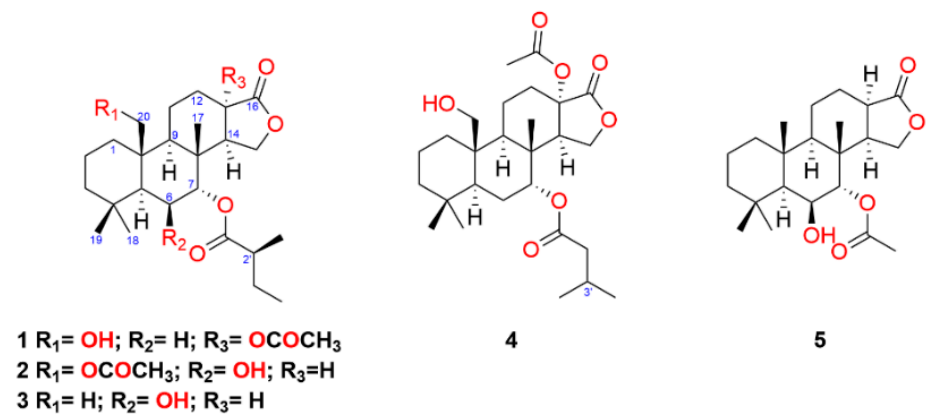

Figure 1. Structures of diterpenes 1-5.

Metabolite 1 was isolated as a colourless oil and displayed a sodiated ion at $\mathrm{m} / \mathrm{z}$ $501.2829[\mathrm{M}+\mathrm{Na}]^{+}$from high-resolution electrospray ionisation mass spectrometry (HRESIMS) for $\mathrm{C}_{27} \mathrm{H}_{42} \mathrm{O}_{7}$. These data indicated an additional seven carbons and five oxygens when compared to spongian-16-one. The ${ }^{1} \mathrm{H}$ and ${ }^{13} \mathrm{C}$ NMR spectroscopic data (Tables 1 and 2; see Supplementary Material) also supported a substituted spongian-16-one skeleton $[4,5]$ but with a methyl singlet at $\delta_{\mathrm{H}} 2.04$ and a triplet signal at $\delta_{\mathrm{H}} 4.85$, suggesting additional functionality, namely an acetate group and substitution at C-7, respectively. Doublet and triplet signals at $\delta_{\mathrm{H}} 1.15(\mathrm{~J}=6.9 \mathrm{~Hz})$ and $\delta_{\mathrm{H}} 0.89(\mathrm{~J}=7.4 \mathrm{~Hz})$, respectively, were attributed to the methyl groups of a 2-methylbutanoate ester, accounting for the remaining five carbon atoms, with gCOSY and HSQC data further validating the $\mathrm{CH}_{3}\left(\mathrm{CH}_{3} \mathrm{CH}_{2}\right) \mathrm{CH}-$ substructure. Signals for three ester carbonyls $\left(\delta_{C} 169.7,174.0\right.$, and 175.4) validated six of the oxygen atoms present in the molecular formula. $\mathrm{HMBC}$ correlations from the signals at $\delta_{\mathrm{H}} 4.85(\mathrm{H}-7, \mathrm{t}, J=2.8 \mathrm{~Hz})$ and $1.15\left(7-\mathrm{OCOCHCH}_{3} \mathrm{CH}_{2} \mathrm{CH}_{3}, \mathrm{~d}\right)$ to the signal at $\delta_{\mathrm{C}} 175.4$ confirmed the 2-methylbutanoate group at C-7. Noting that the $J$ values of $\mathrm{H}-14\left(\delta_{\mathrm{H}} 2.92\right.$, $\mathrm{dd}, J=1.5,6.5 \mathrm{~Hz}$ ) for $\mathbf{1}$ were different from those observed in spongian-16-one (Kernan et al.: 2.07, dd, $J=5.0,8.0 \mathrm{~Hz}$; Hambley et al.: 2.09, dd, $J=5.4,8.0 \mathrm{~Hz})$ [4,5], HMBC correlations from $\mathrm{H}-12 \mathrm{eq}\left(\delta_{\mathrm{H}} 2.28\right), \mathrm{H}-14\left(\delta_{\mathrm{H}} 2.92\right)$ and $\mathrm{H}-15 \mathrm{ax}\left(\delta_{\mathrm{H}} 4.20\right)$, as well as the signals at $\delta_{\mathrm{H}} 2.04\left(13-\mathrm{OCOCH}_{3}\right)$ and $2.92(\mathrm{H}-14)$ to the signal at $\delta_{\mathrm{C}} 81.1(\mathrm{C}-13)$, located the acetate group at $\mathrm{C}-13$. The signal for Me-20 of spongian-16-one [4,5] was replaced by signals for an oxymethylene $\mathrm{H}_{2}-20\left(\delta_{\mathrm{H}} 4.05\right.$ and $\left.\delta_{\mathrm{H}} 3.92\right)$ in 1 . These proton chemical shifts were inconsistent with esterification at C-20 [7,30]; therefore, a hydroxy group was located at $\mathrm{C}-20$, identifying the final oxygen atom. NOESY correlations observed between H-7/Me-17 and $\mathrm{H}_{2}-20 / \mathrm{Me}-17$ confirmed the same relative configuration as spongian-16-one; however, the configuration of the acetate at C-13 and the 2'-methyl in the 2-methylbutanoate substituent could not be determined by NMR methods. Metabolite 1 was crystallized 
from $10 \%$ EtOAc/hexanes, producing small needle-shaped crystals which were suitable for diffraction. The resulting crystal structure obtained established the overall relative configuration. The absolute configuration was assigned as $5 S, 7 R, 8 R, 9 R, 10 R, 13 S, 14 R$, $2^{\prime} S$; within naturally-occurring 2-alkylalkanoic acid derivatives, the $2^{\prime} S$ configuration is favoured [31]. In 1, the cyclohexane rings $\mathrm{A}, \mathrm{B}$, and $\mathrm{C}$ each adopt a chair conformation. As a result, adjacent molecules interact through hydrogen bonds $\mathrm{O}(7) \mathrm{H} \bullet \bullet \bullet \mathrm{O}(4)=2.17 \AA, 167^{\circ}$, resulting in the formation of an undulating one-dimensional polymeric chain that extends down parallel to the crystallographic $a$-axis (Figure 2). The name of compound $\mathbf{1}$ was assigned as (-)-13-acetoxy-20-hydroxy-7 $\alpha$-oxyspongian-16-one-7 $\alpha$-(2-methyl)-butanoate.

Table 1. ${ }^{1} \mathrm{H}$ NMR assignments for spongian-16-one analogues $1-5^{a}$.

\begin{tabular}{|c|c|c|c|c|c|}
\hline \multirow{2}{*}{ Position } & \multicolumn{5}{|c|}{$\delta_{\mathrm{H}}$, mult., $J(\mathrm{~Hz})$} \\
\hline & $1^{b}$ & $2^{c}$ & $3^{c, e}$ & $4^{c}$ & $5^{b}$ \\
\hline $1 \mathrm{eq}$ & 2.22, br d $(12.5)$ & $2.34, \mathrm{~m}$ & $1.75, \mathrm{~m}$ & $2.22, \mathrm{~m}$ & $1.74, \mathrm{~m}$ \\
\hline $1 \mathrm{ax}$ & $0.89, \mathrm{~m}$ & $0.78, \mathrm{~m}$ & $0.86, \mathrm{~m}$ & $0.89, \mathrm{~m}$ & $0.86, \mathrm{~m}$ \\
\hline $2 \mathrm{eq}$ & $1.60, \mathrm{~m}$ & $1.61, \mathrm{~m}$ & $1.73, \mathrm{~m}$ & $1.61, \mathrm{~m}$ & $1.71, \mathrm{~m}$ \\
\hline $2 a x^{1}$ & $1.51, \mathrm{~m}$ & $1.46, \mathrm{~m}$ & $1.46, \mathrm{~m}$ & $1.51, \mathrm{~m}$ & $1.46, \mathrm{~m}$ \\
\hline $3 e q$ & $1.49, \mathrm{~m}$ & $1.45, \mathrm{~m}$ & $1.39, \mathrm{~m}$ & $1.48, \mathrm{~m}$ & $1.39, \mathrm{~m}$ \\
\hline $3 a x$ & $1.23, \mathrm{~m}$ & $1.24, \mathrm{~m}$ & $1.19, \mathrm{~m}$ & $1.24, \mathrm{~m}$ & $1.20, \mathrm{~m}$ \\
\hline 4 & - & - & - & - & - \\
\hline 5 & $1.45, \mathrm{~m}$ & 1.38, br s & 1.16, & $1.50, \mathrm{~m}$ & $1.16, \mathrm{~d}(2.0)$ \\
\hline $6 \mathrm{eq}$ & $1.81, \mathrm{~m}$ & 4.17 , br s & 4.18, br s & $1.81, \mathrm{~m}$ & 4.19, br s \\
\hline $6 a x$ & $1.63, \mathrm{~m}$ & - & - & $1.63, \mathrm{~m}$ & - \\
\hline $7 e q$ & $4.85, \mathrm{t}(2.8)$ & $4.87, \mathrm{~d}(3.2)$ & $4.84, \mathrm{~d}(2.6)$ & $4.86, \mathrm{t}(2.6)$ & $4.84, \mathrm{~d}(3.1)$ \\
\hline $7 a x$ & - & - & - & - & - \\
\hline 8 & - & - & - & - & - \\
\hline 9 & $1.49, \mathrm{~m}$ & $1.14, \mathrm{~m}$ & $1.05, \mathrm{~m}$ & $1.44, \mathrm{~m}$ & $1.05, \mathrm{dd}(2.2,12.5)$ \\
\hline 10 & - & - & - & - & - \\
\hline 11 eq & $1.92, \mathrm{~m}$ & $1.80, \mathrm{~m}$ & $1.58, \mathrm{~m}$ & $1.88, \mathrm{~m}$ & $1.57, \mathrm{~m}$ \\
\hline $11 a x$ & $1.89, \mathrm{~m}$ & $1.58, \mathrm{~m}$ & $1.47, \mathrm{~m}$ & $1.88, \mathrm{~m}$ & $1.45, \mathrm{~m}$ \\
\hline $12 \mathrm{eq}$ & $2.28, \operatorname{dt}(13.9,5.8)$ & $2.31, \mathrm{~m}$ & $2.32, \mathrm{~m}$ & $2.32, \operatorname{dt}(14.1,5.6)$ & $2.32, \mathrm{~m}$ \\
\hline $12 \mathrm{ax}$ & $2.02, \mathrm{~m}$ & $1.55, \mathrm{~m}$ & $1.60, \mathrm{~m}$ & $1.99, \mathrm{~m}$ & $1.60, \mathrm{~m}$ \\
\hline 13 & - & $2.57, \mathrm{t}(7.9)$ & $2.57, \mathrm{t}(7.8)$ & - & $2.60, \mathrm{t}(8.2)$ \\
\hline 14 & $2.92, \mathrm{dd}(1.5,6.5)$ & $2.49, \mathrm{~m}$ & $2.44, \mathrm{dd}(5.6,7.8)$ & $2.91, \mathrm{dd}(1.2,6.3)$ & $2.43, \mathrm{dd}(5.6,8.2)$ \\
\hline $15 \mathrm{eq}$ & $4.22, \mathrm{dd}(6.5,9.9)$ & $4.25, \mathrm{~d}(10.2)$ & $4.27, \mathrm{~d}(10.1)$ & 4.25, dd $(6.3,9.9)$ & $4.26, \mathrm{~d}(10.2)$ \\
\hline $15 a x$ & $4.20, \operatorname{dd}(1.5,9.9)$ & $3.94, \mathrm{dd}(5.5,10.2)$ & 3.95, dd $(5.6,10.1)$ & $4.20, \mathrm{dd}(1.2,9.9)$ & 3.98, dd $(5.6,10.2)$ \\
\hline 16 & - & - & - & - & - \\
\hline 17 & $1.10, \mathrm{~s}$ & $1.27, \mathrm{~s}$ & $1.22, \mathrm{~s}$ & $1.09, \mathrm{~s}$ & $1.21, \mathrm{~s}$ \\
\hline $18 \mathrm{eq}$ & $0.81, \mathrm{~s}$ & $0.90, \mathrm{~s}$ & $0.90, \mathrm{~s}$ & $0.81, \mathrm{~s}$ & $0.90, \mathrm{~s}$ \\
\hline $19 a x$ & $0.81, \mathrm{~s}$ & $1.18, \mathrm{~s}$ & $1.19, \mathrm{~s}$ & $0.80, \mathrm{~s}$ & $1.19, \mathrm{~s}$ \\
\hline $20 a$ & $4.05, \mathrm{~d}(11.8)$ & $4.79, \mathrm{~m}$ & & $4.04, \mathrm{~d}(11.8)$ & \\
\hline $20 b$ & $3.92, \mathrm{~d}(11.8)$ & $4.73, \mathrm{~m}$ & $1.19, \mathrm{~s}$ & $3.91, \mathrm{~d}(11.8)$ & $1.19, \mathrm{~s}$ \\
\hline 6-OH & - & $d$ & $d$ & - & $d$ \\
\hline $7-\mathrm{CO}_{2} \mathrm{CH}_{3}$ & - & - & - & - & $2.09, \mathrm{~s}$ \\
\hline $7-\mathrm{CO}_{2} \mathrm{CH}_{2} \mathrm{CH}\left(\mathrm{CH}_{3}\right)_{2}$ & - & - & - & $\begin{array}{l}2.22, \mathrm{~m} \\
2.22, \mathrm{~m}\end{array}$ & - \\
\hline $7-\mathrm{CO}_{2} \mathrm{CH}_{2} \mathrm{CH}\left(\mathrm{CH}_{3}\right)_{2}$ & - & - & - & $2.11, \mathrm{~m}$ & - \\
\hline $7-\mathrm{CO}_{2} \mathrm{CH}_{2} \mathrm{CH}\left(\mathrm{CH}_{3}\right)_{2}$ & - & - & - & $\begin{array}{l}0.95, \mathrm{~d}(6.6) \\
0.96, \mathrm{~d}(6.6)\end{array}$ & - \\
\hline $7-\mathrm{CO}_{2} \mathrm{CHCH}_{3} \mathrm{CH}_{2} \mathrm{CH}_{3}$ & $2.40, \mathrm{~m}(7.1)$ & $2.41, \mathrm{q}(6.9)$ & $2.45, \mathrm{~m}$ & - & - \\
\hline $7-\mathrm{CO}_{2} \mathrm{CHCH}_{3} \mathrm{CH}_{2} \mathrm{CH}_{3}$ & $1.15, \mathrm{~d}(6.9)$ & $1.15, \mathrm{~d}(6.9)$ & $1.15, \mathrm{~d}(7.2)$ & - & - \\
\hline $7-\mathrm{CO}_{2} \mathrm{CHCH}_{3} \mathrm{CH}_{2} \mathrm{CH}_{3}$ & $\begin{array}{c}1.68, \mathrm{dt}(13.6,7.4) \\
1.48, \mathrm{~m}\end{array}$ & $\begin{array}{c}1.68, \mathrm{dt}(13.6,7.4) \\
1.50, \mathrm{~m}\end{array}$ & $\begin{array}{l}1.68, \mathrm{~m} \\
1.49, \mathrm{~m}\end{array}$ & - & - \\
\hline $7-\mathrm{CO}_{2} \mathrm{CHCH}_{3} \mathrm{CH}_{2} \mathrm{CH}_{3}$ & $0.89, \mathrm{t}(7.4)$ & $0.91, \mathrm{t}(7.4)$ & $0.90, \mathrm{t}(7.2)$ & - & - \\
\hline $13-\mathrm{CO}_{2} \mathrm{CH}_{3}$ & $2.04, \mathrm{~s}$ & - & - & $2.04, \mathrm{~s}$ & - \\
\hline $20-\mathrm{CO}_{2} \mathrm{CH}_{3}$ & - & $2.03, \mathrm{~s}$ & - & - & - \\
\hline $20-\mathrm{OH}$ & $d$ & - & - & $d$ & - \\
\hline
\end{tabular}

${ }^{a}$ Chemical shifts (ppm) referenced to $\mathrm{CHCl}_{3}\left(\delta_{\mathrm{H}} 7.26, \delta_{\mathrm{C}} 77.16\right) .{ }^{b}$ At $500 \mathrm{MHz} .{ }^{c}$ At $700 \mathrm{MHz} .{ }^{d}$ Not observed. ${ }^{e}$ Data acquired using a Shigemi NMR tube. 
Table 2. ${ }^{13} \mathrm{C}$ NMR assignments for spongian-16-one analogues $1-5^{a}$.

\begin{tabular}{|c|c|c|c|c|c|}
\hline \multirow{2}{*}{ Position } & \multicolumn{5}{|c|}{$\delta_{C}$, mult. } \\
\hline & $1^{b}$ & $2^{c}$ & $3^{c, d}$ & $4^{c}$ & $5^{b}$ \\
\hline 1 & $34.6, \mathrm{CH}_{2}$ & $36.6, \mathrm{CH}_{2}$ & $42.4, \mathrm{CH}_{2}$ & $34.9, \mathrm{CH}_{2}$ & $42.4, \mathrm{CH}_{2}$ \\
\hline 2 & $18.7, \mathrm{CH}_{2}$ & $18.6, \mathrm{CH}_{2}$ & $18.7, \mathrm{CH}_{2}$ & $18.8, \mathrm{CH}_{2}$ & $18.7, \mathrm{CH}_{2}$ \\
\hline 3 & $41.7, \mathrm{CH}_{2}$ & $43.4, \mathrm{CH}_{2}$ & $44.1, \mathrm{CH}_{2}$ & $41.7, \mathrm{CH}_{2}$ & $43.9, \mathrm{CH}_{2}$ \\
\hline 4 & $32.2, \mathrm{C}$ & $33.5, \mathrm{C}$ & $33.7, \mathrm{C}$ & $32.3, \mathrm{C}$ & $33.2, \mathrm{C}$ \\
\hline 5 & $48.1, \mathrm{CH}$ & $51.8, \mathrm{CH}$ & $51.3, \mathrm{CH}$ & $47.9, \mathrm{CH}$ & $51.2, \mathrm{CH}$ \\
\hline 6 & $23.1, \mathrm{CH}_{2}$ & $69.6, \mathrm{CH}$ & $70.6, \mathrm{CH}$ & 23.1, $\mathrm{CH}_{2}$ & $70.5, \mathrm{CH}$ \\
\hline 7 & $73.4, \mathrm{CH}$ & $75.2, \mathrm{CH}$ & $75.7, \mathrm{CH}$ & $73.6, \mathrm{CH}$ & $76.1, \mathrm{CH}$ \\
\hline 8 & $39.5, \mathrm{C}$ & $37.9, \mathrm{C}$ & $37.7, \mathrm{C}$ & $39.3, \mathrm{C}$ & $37.7, \mathrm{C}$ \\
\hline 9 & $50.1, \mathrm{CH}$ & $52.4, \mathrm{CH}$ & $51.9, \mathrm{CH}$ & $50.3, \mathrm{CH}$ & $51.8, \mathrm{CH}$ \\
\hline 10 & $39.5, \mathrm{C}$ & $40.8, \mathrm{C}$ & $36.8, \mathrm{C}$ & $41.5, \mathrm{C}$ & $36.7, \mathrm{C}$ \\
\hline 11 & $18.7, \mathrm{CH}_{2}$ & $19.1, \mathrm{CH}_{2}$ & $17.4, \mathrm{CH}_{2}$ & $18.8, \mathrm{CH}_{2}$ & $17.4, \mathrm{CH}_{2}$ \\
\hline 12 & $27.3, \mathrm{CH}_{2}$ & $22.5, \mathrm{CH}_{2}$ & $21.8, \mathrm{CH}_{2}$ & $27.5, \mathrm{CH}_{2}$ & $22.0, \mathrm{CH}_{2}$ \\
\hline 13 & $81.1, \mathrm{C}$ & $36.9, \mathrm{CH}$ & $37.0, \mathrm{CH}$ & $81.0, \mathrm{CH}$ & $37.0, \mathrm{CH}$ \\
\hline 14 & $45.9, \mathrm{CH}$ & $41.9, \mathrm{CH}$ & 41.6, CH & $45.9, \mathrm{CH}$ & $41.9, \mathrm{CH}$ \\
\hline 15 & $66.9, \mathrm{CH}_{2}$ & $67.1, \mathrm{CH}_{2}$ & $67.2, \mathrm{CH}_{2}$ & $66.9, \mathrm{CH}_{2}$ & $67.4, \mathrm{CH}_{2}$ \\
\hline 16 & 174.0, C & $178.5, \mathrm{C}$ & $178.9, \mathrm{C}$ & $173.7, \mathrm{C}$ & $178.9, \mathrm{C}$ \\
\hline 17 & $16.1, \mathrm{CH}_{3}$ & $15.1, \mathrm{CH}_{3}$ & $15.0, \mathrm{CH}_{3}$ & $15.9, \mathrm{CH}_{3}$ & $14.9, \mathrm{CH}_{3}$ \\
\hline $18 \mathrm{eq}$ & $33.4, \mathrm{CH}_{3}$ & $33.8, \mathrm{CH}_{3}$ & $33.2, \mathrm{CH}_{3}$ & $33.6, \mathrm{CH}_{3}$ & $33.4, \mathrm{CH}_{3}$ \\
\hline $19 a x$ & $21.8, \mathrm{CH}_{3}$ & $24.6, \mathrm{CH}_{3}$ & $24.3, \mathrm{CH}_{3}$ & $21.9, \mathrm{CH}_{3}$ & $24.5, \mathrm{CH}_{3}$ \\
\hline 20 & 62.1, $\mathrm{CH}_{2}$ & 64.1, $\mathrm{CH}_{2}$ & $17.6, \mathrm{CH}_{3}$ & 62.1, $\mathrm{CH}_{2}$ & 18.0, $\mathrm{CH}_{3}$ \\
\hline 7- $\mathrm{CO}_{2} \mathrm{CH}_{3}$ & - & - & - & - & $169.7, \mathrm{C}$ \\
\hline $7-\mathrm{CO}_{2} \mathrm{CH}_{3}$ & - & - & - & & 21.4, $\mathrm{CH}_{3}$ \\
\hline $7-\mathrm{CO}_{2} \mathrm{CH}_{2} \mathrm{CH}\left(\mathrm{CH}_{3}\right)_{2}$ & - & - & - & $171.9, \mathrm{C}$ & - \\
\hline $7-\mathrm{CO}_{2} \mathrm{CH}_{2} \mathrm{CH}\left(\mathrm{CH}_{3}\right)_{2}$ & - & - & - & $44.0, \mathrm{CH}_{2}$ & - \\
\hline $7-\mathrm{CO}_{2} \mathrm{CH}_{2} \mathrm{CH}\left(\mathrm{CH}_{3}\right)_{2}$ & - & - & - & $25.7, \mathrm{CH}$ & \\
\hline $7-\mathrm{CO}_{2} \mathrm{CH}_{2} \mathrm{CH}\left(\mathrm{CH}_{3}\right)_{2}$ & - & - & - & $\begin{array}{l}22.5, \mathrm{CH}_{3} \\
22.5, \mathrm{CH}_{3}\end{array}$ & - \\
\hline $7-\mathrm{CO}_{2} \mathrm{CHCH}_{3} \mathrm{CH}_{2} \mathrm{CH}_{3}$ & $175.4, \mathrm{C}$ & $174.9, \mathrm{C}$ & $175.3, \mathrm{C}$ & - & - \\
\hline $7-\mathrm{CO}_{2} \mathrm{CHCH}_{3} \mathrm{CH}_{2} \mathrm{CH}_{3}$ & $41.8, \mathrm{CH}$ & $41.2, \mathrm{CH}$ & $41.6, \mathrm{CH}$ & - & - \\
\hline $7-\mathrm{CO}_{2} \mathrm{CHCH}_{3} \mathrm{CH}_{2} \mathrm{CH}_{3}$ & $16.9, \mathrm{CH}_{3}$ & $16.9, \mathrm{CH}_{3}$ & $16.9, \mathrm{CH}_{3}$ & - & - \\
\hline $7-\mathrm{CO}_{2} \mathrm{CHCH}_{3} \mathrm{CH}_{2} \mathrm{CH}_{3}$ & $26.8, \mathrm{CH}_{2}$ & $26.8, \mathrm{CH}_{2}$ & $26.9, \mathrm{CH}_{2}$ & - & - \\
\hline $7-\mathrm{CO}_{2} \mathrm{CHCH}_{3} \mathrm{CH}_{2} \mathrm{CH}_{3}$ & $11.8, \mathrm{CH}_{3}$ & $11.8, \mathrm{CH}_{3}$ & $11.7, \mathrm{CH}_{3}$ & - & - \\
\hline $13-\mathrm{CO}_{2} \mathrm{CH}_{3}$ & $169.7, \mathrm{C}$ & - & - & 169.6, C & - \\
\hline $13-\mathrm{CO}_{2} \mathrm{CH}_{3}$ & $21.5, \mathrm{CH}_{3}$ & - & - & 21.6, $\mathrm{CH}_{3}$ & - \\
\hline $20-\mathrm{CO}_{2} \mathrm{CH}_{3}$ & - & $170.6, \mathrm{C}$ & - & - & - \\
\hline $20-\mathrm{CO}_{2} \mathrm{CH}_{3}$ & - & $21.2, \mathrm{CH}_{3}$ & - & - & - \\
\hline
\end{tabular}

${ }^{a}$ Chemical shifts (ppm) referenced to $\mathrm{CHCl}_{3}\left(\delta_{\mathrm{H}} 7.26, \delta_{\mathrm{C}} 77.16\right) .{ }^{b}$ At $500 \mathrm{MHz} .{ }^{c}$ At $700 \mathrm{MHz} .{ }^{d}$ Data acquired using a Shigemi NMR tube. 


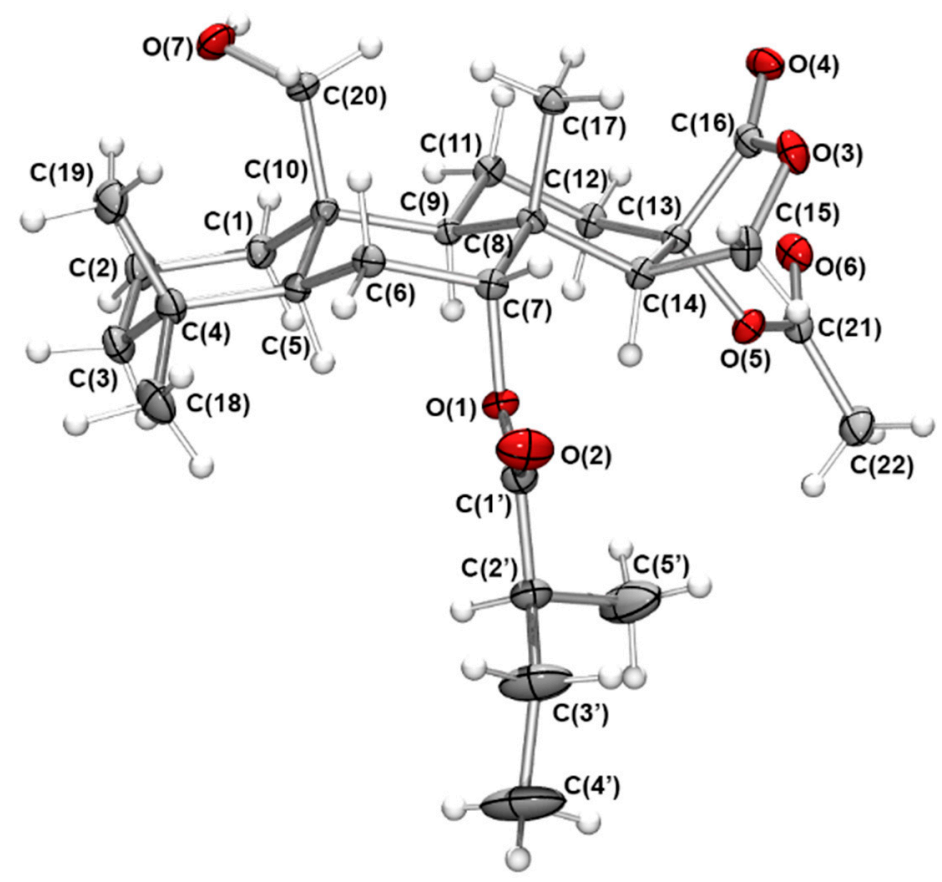

Figure 2. Oak Ridge Thermal Ellipsoid Plot (ORTEP) [32] representation of the crystal structure of $(5 S, 7 R, 8 R, 9 R, 10 R, 13 S, 14 R, 2 ' S)$-13-acetoxy-20-hydroxy-7 $\alpha$-oxyspongian-16-one-7 $\alpha$-(2-methyl)butanoate (1) shown with $30 \%$ probability ellipsoids.

Diterpene 2 was isolated as a colourless oil and found to have the same $\mathrm{C}_{27} \mathrm{H}_{42} \mathrm{O}_{7}$ molecular formula as 1 inferred from HRESIMS $\left(\mathrm{m} / z 501.2824[\mathrm{M}+\mathrm{Na}]^{+}\right)$. Examination of the ${ }^{1} \mathrm{H}$ and ${ }^{13} \mathrm{C}$ NMR spectroscopic data (Tables 1 and 2) revealed similar signals to those of 1 , including a methyl doublet at $\delta_{\mathrm{H}} 1.15(\mathrm{~J}=6.9 \mathrm{~Hz})$ and a methyl triplet at $\delta_{\mathrm{H}}$ $0.91(\mathrm{~J}=7.4 \mathrm{~Hz})$ for the methyl groups of a 2-methylbutanoate ester; there was also an acetate methyl singlet at $\delta_{\mathrm{H}} 2.03$. HMBC correlations from the signals at $\delta_{\mathrm{H}} 4.87(\mathrm{H}-7, \mathrm{~d}$, $J=3.2 \mathrm{~Hz})$ and $1.15\left(7-\mathrm{OCOCHCH}_{3} \mathrm{CH}_{2} \mathrm{CH}_{3}, \mathrm{~d}\right)$ to the signal at $\delta_{\mathrm{C}} 174.9$ confirmed the 2-methylbutanoate group at C-7. The configuration of the $2^{\prime}$-methyl in the ester sidechain could not be established further, owing to the small sample size, but was selected as identical to that in 1 on biogenetic considerations. HMBC correlations from $\mathrm{H}-20 \mathrm{a}\left(\delta_{\mathrm{H}}\right.$ 4.79) and $\mathrm{H}-20 \mathrm{~b}\left(\delta_{\mathrm{H}} 4.73\right)$ to the signal at $\delta_{\mathrm{C}} 170.6$ confirmed the position of the acetoxy group at C-20; there were NOESY correlations between $\mathrm{H}_{2}-20 / \mathrm{Me}-17$ and $\mathrm{H}-20 \mathrm{~b} / \mathrm{Me}-19$. The doublet appearance of $\mathrm{H}-7(\mathrm{~J}=3.2 \mathrm{~Hz})$ was initially considered consistent with an equatorial $\mathrm{OH}$ group at $\mathrm{C}-6$; however, the signal for $\mathrm{H}-5$ was a broadened singlet rather than the doublet with a large $J$ value anticipated if H-6 was axial, (cf. aplyroseol-19 from Chromodoris reticulata [33]). The NOESY correlation between H-6/Me-18 supported an equatorial H-6, while the absence of an NOE between H-6 and Me-17, although not diagnostic, was also consistent with the changed configuration at C-6 compared to that in aplyroseol-19 [33]. The NOESY correlation between H-7/Me-17 placed the C-7 ester substituent on the opposite face to Me-17. Compound 2 was assigned the systematic name (-)-20-acetoxy-6 $\beta$-hydroxy-7 $\alpha$-oxyspongian-16-one-7 $\alpha$-(2-methyl)-butanoate.

Metabolite 3, also isolated as a colourless oil, displayed an adduct ion at $m / z 443.2779$ $[\mathrm{M}+\mathrm{Na}]^{+}$in HRESIMS analysis, which established the molecular formula as $\mathrm{C}_{25} \mathrm{H}_{40} \mathrm{O}_{5}$ with an additional five carbons and three oxygens compared with spongian-16-one. Due to the small sample quantity $(<0.1 \mathrm{mg})$, a Shigemi tube was employed to increase the sensitivity of NMR signal detection [34]. The spectroscopic data again revealed a 2methylbutanoate moiety, located at C-7 from the identical HMBC correlations for H-7 to those in $\mathbf{1}$ and $\mathbf{2}$. NOESY data could not be obtained, but the similar appearance of the signals for $\mathrm{H}-6\left(\delta_{\mathrm{H}} 4.18, \mathrm{br} \mathrm{s}\right)$ and $\mathrm{H}-7\left(\delta_{\mathrm{H}} 4.84, J=2.6 \mathrm{~Hz}\right)$ compared to 2 established the axial hydroxy group at C-6 and the equatorial ester group at C-7. The $7.8 \mathrm{~Hz}$ coupling 
between $\mathrm{H}-13$ and $\mathrm{H}-14$ assigned the cis $\mathrm{C} / \mathrm{D}$ ring junction. The name of compound 3 was assigned as (-)-6 $\beta$-hydroxy-7 $\alpha$-oxyspongian-16-one-7 $\alpha$-(2-methyl)-butanoate.

Diterpene 4, a colourless oil, exhibited an adduct ion at $\mathrm{m} / z 501.2831[\mathrm{M}+\mathrm{Na}]^{+}$ in the HRESIMS, corresponding to a molecular formula of $\mathrm{C}_{27} \mathrm{H}_{42} \mathrm{O}_{7}$, which was the same molecular formula observed for $\mathbf{1}$ and 2 . The ${ }^{1} \mathrm{H}$ and ${ }^{13} \mathrm{C}$ NMR spectroscopic data revealed an acetate methyl singlet at $\delta_{\mathrm{H}} 2.04$ as well as oxymethylene signals at $\delta_{\mathrm{H}} 4.04$ $(\mathrm{d}, J=11.8 \mathrm{~Hz})$ and $3.91(\mathrm{~d}, J=11.8 \mathrm{~Hz})$ for $\mathrm{H}_{2}-20$, similar to comparable signals for $\mathbf{1}$, and suggesting a $\mathrm{C}-20$ hydroxy group. The major difference compared to the data for $\mathbf{1}$ was the presence of two methyl doublets at $\delta_{\mathrm{H}} 0.95(\mathrm{~d}, J=6.6 \mathrm{~Hz})$ and $0.96(\mathrm{~d}, J=6.6 \mathrm{~Hz})$ suggesting a 3-methylbutanoate substituent. There were gCOSY correlations from the $\mathrm{H}-3^{\prime}$ methine $\left(\delta_{\mathrm{H}} 2.11, \mathrm{~m}\right)$ to both Me- $4^{\prime}$ and Me- $5^{\prime}$ and $\mathrm{H}_{2}-2^{\prime}\left(\delta_{\mathrm{H}} 2.22, \mathrm{~m}, 2 \mathrm{H}\right)$. HMBC correlations from the signals at $\delta_{\mathrm{H}} 4.86(\mathrm{H}-7, \mathrm{t}, J=2.6 \mathrm{~Hz}), 2.11\left(7-\mathrm{OCOCH}_{2} \mathrm{CH}\left(\mathrm{CH}_{3}\right)_{2}, \mathrm{~m}, \mathrm{H}-3^{\prime}\right)$ and the methylene signals at $\delta_{\mathrm{H}} 2.22\left(7-\mathrm{OCOCH}_{2} \mathrm{CH}\left(\mathrm{CH}_{3}\right)_{2}, \mathrm{~m}, \mathrm{H}_{2}-2^{\prime}\right)$ to the carbon at $\delta_{\mathrm{C}} 171.9$ confirmed the 3-methylbutanoate group was attached at C-7. These ${ }^{1} \mathrm{H}$ chemical shifts and HMBC correlations were comparable to those of $7 \alpha-11 \alpha$-dioxyspongian-16-one- $7 \alpha-$ isopentanoate- $11 \alpha$-propionate [7]. The similarity of the signal pattern and chemical shift of $\mathrm{H}-14\left(\delta_{\mathrm{H}} 2.91, \mathrm{dd}, J=1.2,6.3 \mathrm{~Hz}\right)$ to that in 1 , together with $\mathrm{HMBC}$ correlations from the signals at $\delta_{\mathrm{H}} 2.04\left(13-\mathrm{OCOCH}_{3}\right)$ and $2.91(\mathrm{H}-14)$ to the carbon at $\delta_{\mathrm{C}} 81.0(\mathrm{C}-13)$ confirmed an acetate group at C-13. NOESY correlations determined the relative configuration of C-7 and C-10 to be identical to those of $\mathbf{1}$ and $\mathbf{2}$. X-ray studies (See Supplementary Materials) supported the configuration of $\mathrm{C}-13$ to be the same as in 1 . Compound 4 was assigned the name (-)-13-acetoxy-20-hydroxy-7 $\alpha$-oxyspongian-16-one-7 $\alpha$-(3-methyl)-butanoate.

Diterpene 5 was isolated as a colourless oil and displayed a sodiated molecular ion peak by HRESIMS at $\mathrm{m} / \mathrm{z} 401.2293[\mathrm{M}+\mathrm{Na}]^{+}$, corresponding to a molecular formula of $\mathrm{C}_{22} \mathrm{H}_{34} \mathrm{O}_{5}$. The ${ }^{1} \mathrm{H}$ and ${ }^{13} \mathrm{C}$ NMR spectroscopic data (Tables 1 and 2) showed an acetoxy methyl singlet at $\delta_{\mathrm{H}} 2.09$ and associated carbonyl signal at $\delta_{\mathrm{C}} 169.7$, comparable to those in the NMR data of $7 \alpha$-acetoxyspongian-16-one [28]. HMBC correlations from the signals at $\delta_{\mathrm{H}} 2.09$ and $4.84(\mathrm{H}-7, \mathrm{~d}, J=3.1 \mathrm{~Hz})$ to the carbonyl at $\delta_{\mathrm{C}} 169.7$ confirmed the position of the acetoxy group at C-7. The doublet appearance of $\mathrm{H}-7$ suggested hydroxy substitution at C-6. The relative configuration of $\mathbf{5}$ was identical to that of $\mathbf{2}$ from the NOESY correlations between H-6/Me-18, H-7/Me-17, H-5/H-9, and H-9/H-14. Compound 5 was assigned the systematic name (-)-7 $\alpha$-acetoxy- $6 \beta$-hydroxyspongian-16-one.

\subsection{Diterpenes from Goniobranchus $s p .1$}

Three specimens of Goniobranchus sp. 1 were collected from Mudjimba and Gneerings Reefs, South East Queensland, Australia. The extraction and chemical profile of the metabolites from the mantle and viscera tissue were carried out based on the previously described procedures. A total of fifteen spongian diterpene metabolites were isolated from Goniobranchus sp 1, including the new spongian-16-one analogues 6-11. From the mantle isoagatholactone [3], $12 \alpha$-acetoxyspongian-16-one [30], 20-acetoxyspongian-16-one [30], 20oxyspongian-16-one-propionate [30], 12 $\alpha$,20-dioxyspongian-16-one-dipropionate [30], 12 $\alpha, 20$ diacetoxyspongian-16-one [7], $12 \alpha$-acetoxy-20-oxyspongian-16-one-20-propionate [7], 20acetoxy-12 $\alpha$-oxyspongian-16-one-12 $\alpha$-propionate (6), 20-acetoxy-13-hydroxyspongian-16one (7), 12-hydroxyspongian-16-one (8), 12-hydroxy-20-oxyspongian-16-one-20-propionate (9), 12-hydroxy-11,20-dioxyspongian-16-one-11,20-dipropionate (10), and 11-hydroxy-12,20dioxyspongian-16-one-12,20-dipropionate (11) were also isolated, while the viscera contained spongian-16-one [4,5] and $7 \alpha$-acetoxyspongian-16-one [28]. The known metabolites isoagatholactone, $12 \alpha$-acetoxyspongian-16-one [30], 20-acetoxyspongian-16-one [30], and $12 \alpha$-acetoxy,20-oxyspongian-16-one-20-propionate [7] were isolated from both tissues. The new compounds (6-11) demonstrate a high level of oxidation, in particular at positions C-11, C-12, C-13 and/or C-20 (Figure 3). 


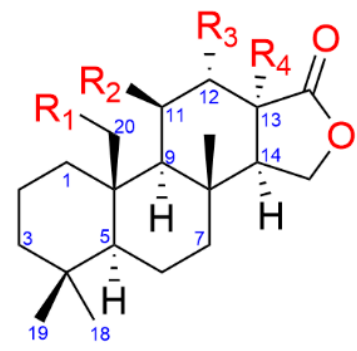

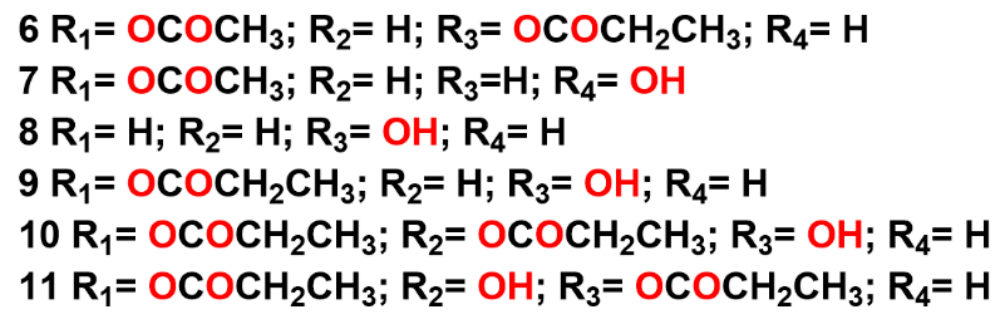

Figure 3. Chemical structures of 6-11.

Diterpene 6 was obtained as a colourless oil from NP-HPLC and exhibited a sodiated molecular ion peak in the HRESIMS at $m / z 457.2566[\mathrm{M}+\mathrm{Na}]^{+}\left(\mathrm{C}_{25} \mathrm{H}_{38} \mathrm{O}_{6}\right)$. The ${ }^{1} \mathrm{H}$ and ${ }^{13} \mathrm{C}$ NMR spectroscopic data (Tables 3 and 4$)$ indicated an acetate group $\left(\delta_{\mathrm{H}} 2.03, \delta_{\mathrm{C}} 21.2\right.$, $170.8)$ while a quartet $(2 \mathrm{H})$ at $\delta_{\mathrm{H}} 2.33$, a triplet at $\delta_{\mathrm{H}} 1.16$ and a carbonyl resonance at $\delta_{\mathrm{C}}$ 173.0 were assigned to a propionate group. The NMR data of $\mathbf{6}$ were found to be similar to those of $12 \alpha$-acetoxy-20-oxyspongian-16-one-20-propionate; however, there were some obvious differences in the location of substituents [7]. Oxymethylene signals at $\delta_{\mathrm{H}} 4.56$ (d) and $4.13(\mathrm{~m})$ corresponded to those of $\mathrm{H}_{2}-20$ in 20-acetoxyspongian-16-one [30]. These two signals, plus the acetate methyl signal at $\delta_{\mathrm{H}} 2.03(\mathrm{~s})$, all correlated to the carbon signal at $\delta_{\mathrm{C}}$ 170.8 and $\mathrm{C}-10\left(\delta_{\mathrm{C}} 39.8\right)$, confirming the position of an acetate group at C-20. The chemical shift values, in particular those of $\mathrm{H}_{2}-11$ and $\mathrm{H}-13$, as well as $\mathrm{C}-12$, were comparable to those in the ${ }^{1} \mathrm{H}$ and ${ }^{13} \mathrm{C}$ NMR spectra of $12 \alpha, 20$-dioxyspongian-16-one-dipropionate [30] thereby establishing the propionate group at C-12. NOESY correlations between $\mathrm{H}-5 / \mathrm{H}-9$, $\mathrm{H}-9 / \mathrm{H}-14, \mathrm{Hb}-20 / \mathrm{Me}-17, \mathrm{H}-20 \mathrm{a} / \mathrm{Me}-19$ and $\mathrm{H}-12 / \mathrm{Me}-17$ placed $\mathrm{H}-12$ and $\mathrm{H}_{2}-20$ on the same face as Me-17. Compound 6 was named (-)-20-acetoxy-12 $\alpha$-oxyspongian-16-one-12 $\alpha$ propionate.

Table 3. ${ }^{1} \mathrm{H}$ NMR assignments for spongian-16-one analogues 6-11 ${ }^{a}$.

\begin{tabular}{|c|c|c|c|c|c|c|}
\hline \multirow{2}{*}{ Position } & \multicolumn{6}{|c|}{$\delta_{\mathrm{H}}$, mult., $J(\mathrm{~Hz})$} \\
\hline & $6^{c}$ & $7^{c}$ & $8^{b}$ & $9^{b}$ & $10^{c}$ & $11^{c}$ \\
\hline $\begin{array}{l}1 \text { eq } \\
1 \mathrm{ax}\end{array}$ & $\begin{array}{l}2.03, \mathrm{~m} \\
0.62, \mathrm{~m}\end{array}$ & $\begin{array}{l}2.12, \mathrm{~m} \\
0.80, \mathrm{~m}\end{array}$ & $\begin{array}{c}1.68, \mathrm{br} \mathrm{d}(12.8) \\
0.83, \mathrm{~m}\end{array}$ & $\begin{array}{c}\text { 2.07, br d }(13.2) \\
0.79, \operatorname{td}(13.2,2.3)\end{array}$ & $\begin{array}{c}2.03, \mathrm{br} \mathrm{d}(13.4) \\
0.75, \mathrm{~m}\end{array}$ & $\begin{array}{c}2.02, \text { br d (13.6) } \\
1.15, \mathrm{~m}\end{array}$ \\
\hline $\begin{array}{l}2 \mathrm{eq} \\
2 \mathrm{ax}\end{array}$ & $\begin{array}{l}1.54, \mathrm{~m} \\
1.43, \mathrm{~m}\end{array}$ & $\begin{array}{l}1.56, \mathrm{~m} \\
1.45, \mathrm{~m}\end{array}$ & $\begin{array}{l}1.61, \mathrm{~m} \\
1.42, \mathrm{~m}\end{array}$ & $\begin{array}{l}\text { 1.57, m } \\
1.46, \mathrm{~m}\end{array}$ & $\begin{array}{l}1.61, \mathrm{~m} \\
1.47, \mathrm{~m}\end{array}$ & $\begin{array}{l}1.62, \mathrm{~m} \\
1.50, \mathrm{~m}\end{array}$ \\
\hline $\begin{array}{l}3 \text { eq } \\
3 a x\end{array}$ & $\begin{array}{l}1.45, \mathrm{~m} \\
1.16, \mathrm{~m}\end{array}$ & $\begin{array}{l}1.45, \mathrm{~m} \\
1.17, \mathrm{~m}\end{array}$ & $\begin{array}{c}1.38, \mathrm{~m} \\
1.15, \operatorname{td}(13.2,3.7)\end{array}$ & $\begin{array}{l}1.45, \mathrm{~m} \\
1.19, \mathrm{~m}\end{array}$ & $\begin{array}{l}1.45, \mathrm{~m} \\
1.16, \mathrm{~m}\end{array}$ & $\begin{array}{c}1.45, \text { br d (12.9) } \\
1.18, \mathrm{~m}\end{array}$ \\
\hline 4 & - & - & - & - & - & - \\
\hline 5 & $1.03, \mathrm{~m}$ & 1.01, dd $(12.4,2.1)$ & $0.89, \mathrm{~m}$ & $1.08, \mathrm{dd}(12.3,1.7)$ & 1.05, dd $(12.7,2.4)$ & $1.11, \mathrm{~m}$ \\
\hline $\begin{array}{l}\text { 6eq } \\
6 a x\end{array}$ & $\begin{array}{l}1.57, \mathrm{~m} \\
1.40, \mathrm{~m}\end{array}$ & $\begin{array}{l}1.56, \mathrm{~m} \\
1.38, \mathrm{~m}\end{array}$ & $\begin{array}{l}1.55, \mathrm{~m} \\
1.35, \mathrm{~m}\end{array}$ & $\begin{array}{l}1.58, \mathrm{~m} \\
1.39, \mathrm{~m}\end{array}$ & $\begin{array}{l}1.66, \mathrm{~m} \\
1.45, \mathrm{~m}\end{array}$ & $\begin{array}{l}1.63, \mathrm{~m} \\
1.49, \mathrm{~m}\end{array}$ \\
\hline $\begin{array}{l}\text { 7eq } \\
7 \text { ax }\end{array}$ & $\begin{array}{l}1.92, \mathrm{~m} \\
1.16, \mathrm{~m}\end{array}$ & $\begin{array}{l}1.88, \mathrm{~m} \\
1.16, \mathrm{~m}\end{array}$ & $\begin{array}{l}\text { 1.82, dt }(12.8,3.3) \\
1.09, \mathrm{dt}(12.8,3.5)\end{array}$ & $\begin{array}{c}1.91, \mathrm{dt}(12.8,3.3) \\
1.17, \mathrm{~m}\end{array}$ & $\begin{array}{c}1.76, \mathrm{dt}(12.6,3.1) \\
1.06, \mathrm{~m}\end{array}$ & $\begin{array}{l}\text { 1.76, dt }(12.6,3.2) \\
1.06, \operatorname{td}(12.6,3.7)\end{array}$ \\
\hline 8 & - & - & - & - & - & - \\
\hline 9 & $1.33, \mathrm{~m}$ & $1.04, \mathrm{~m}$ & $1.32, \mathrm{dd}(9.1,6.3)$ & $1.51, \mathrm{~m}$ & $1.35, \mathrm{~d}(2.9)$ & $1.34, \mathrm{~d}(3.0)$ \\
\hline 10 & - & - & - & - & - & - \\
\hline $\begin{array}{l}11 \text { eq } \\
11 a x\end{array}$ & $\begin{array}{c}2.00, \mathrm{~m} \\
1.80, \mathrm{dd}(13.2,3.4)\end{array}$ & $\begin{array}{l}1.88, \mathrm{~m} \\
1.49, \mathrm{~m}\end{array}$ & $\begin{array}{l}1.63, \mathrm{~m} \\
1.63, \mathrm{~m}\end{array}$ & $\begin{array}{l}1.87, \mathrm{~m} \\
1.85, \mathrm{~m}\end{array}$ & $5.95, \mathrm{t}(3.4)$ & $4.46, \mathrm{t}(3.0)$ \\
\hline $\begin{array}{l}12 \mathrm{eq} \\
12 \mathrm{ax}\end{array}$ & $\begin{array}{c}5.44, \text { br s } \\
-\end{array}$ & $\begin{array}{l}2.63, \mathrm{~m} \\
1.62, \mathrm{~m}\end{array}$ & 4.52, br s & $\begin{array}{c}4.49, \mathrm{br} \mathrm{s} \\
-\end{array}$ & $\begin{array}{c}4.36, \mathrm{~m} \\
-\end{array}$ & $\begin{array}{c}5.54, \text { dd }(9.2,3.0) \\
-\end{array}$ \\
\hline 13 & 2.67 , dt $(8.0,1.5)$ & - & $2.66, \mathrm{~d}(8.0)$ & $2.65, \mathrm{~d}(7.9)$ & $2.84, \mathrm{dd}(10.9,9.4)$ & $3.00, \mathrm{dd}(10.6,9.2)$ \\
\hline 14 & $2.29, \mathrm{dd}(8.0,5.2)$ & $1.94, \mathrm{dd}(7.8,5.6)$ & $2.33, \mathrm{dd}(8.0,5.4)$ & $2.37, \mathrm{dd}(7.9,5.4)$ & $2.44, \mathrm{~m}$ & $2.44, \mathrm{~m}$ \\
\hline
\end{tabular}


Table 3. Cont.

\begin{tabular}{|c|c|c|c|c|c|c|}
\hline \multirow{2}{*}{ Position } & \multicolumn{6}{|c|}{$\delta_{\mathrm{H}}$, mult., $J(\mathrm{~Hz})$} \\
\hline & $6^{c}$ & $7^{c}$ & $8^{b}$ & $9^{b}$ & $10^{c}$ & $11^{c}$ \\
\hline $15 \mathrm{eq}$ & $4.26, \mathrm{~d}(9.9)$ & $4.42, \mathrm{dd}(9.4,5.6)$ & 4.23, d (9.7) & 4.26, d (9.9) & $4.33, \mathrm{~m}$ & $4.28, \mathrm{~m}$ \\
\hline $15 a x$ & $4.12, \mathrm{~m}$ & 4.13, dd $(9.4,7.8)$ & $4.11, \mathrm{dd}(9.7,5.4)$ & $4.13, \mathrm{dd}(9.9,5.4)$ & $4.33, \mathrm{~m}$ & $4.28, \mathrm{~m}$ \\
\hline 16 & & & & & & \\
\hline 17 & $0.90, \mathrm{~s}$ & $0.88, \mathrm{~s}$ & $0.82, \mathrm{~s}$ & $0.89, \mathrm{~s}$ & $0.95, \mathrm{~s}$ & $0.94, \mathrm{~s}$ \\
\hline $18 \mathrm{eq}$ & $0.89, \mathrm{~s}$ & $0.89, \mathrm{~s}$ & $0.86, \mathrm{~s}$ & $0.90, \mathrm{~s}$ & $0.87, \mathrm{~s}$ & $0.87, \mathrm{~s}$ \\
\hline $19 a x$ & $0.83, \mathrm{~s}$ & $0.83, \mathrm{~s}$ & $0.81, \mathrm{~s}$ & $0.85, \mathrm{~s}$ & $0.81, \mathrm{~s}$ & $0.82, \mathrm{~s}$ \\
\hline $20 \mathrm{a}$ & $4.56, \mathrm{~d}(12.4)$ & $4.55, \mathrm{~d}(13.1)$ & $082 \mathrm{~s}$ & $4.59, \mathrm{~d}(12.1)$ & $4.74, \mathrm{~d}(12.0)$ & $4.61, \mathrm{~d}(12.2)$ \\
\hline $20 \mathrm{~b}$ & $4.13, \mathrm{~m}$ & $4.14, \mathrm{~d}(13.1)$ & $0.82, \mathrm{~s}$ & $4.17, \mathrm{~d}(12.1)$ & 3.96 , dd $(12.0,1.9)$ & 4.02, dd $(12.2,1.8)$ \\
\hline $11-\mathrm{OH}$ & - & - & - & - & - & 2.08 , br s \\
\hline $11-\mathrm{CO}_{2} \mathrm{CH}_{2} \mathrm{CH}_{3}$ & - & - & - & - & $\begin{array}{l}2.34, \mathrm{~m} \\
2.34, \mathrm{~m}\end{array}$ & - \\
\hline $11-\mathrm{CO}_{2} \mathrm{CH}_{2} \mathrm{CH}_{3}$ & - & - & - & - & $1.15, \mathrm{t}(7.7)$ & - \\
\hline $12-\mathrm{OH}$ & - & - & $d$ & $d$ & $2.79, \mathrm{br} \mathrm{s}$ & - \\
\hline $12-\mathrm{OCOCH}_{3}$ & - & - & - & - & - & - \\
\hline $12-\mathrm{CO}_{2} \mathrm{CH}_{2} \mathrm{CH}_{3}$ & $\begin{array}{l}2.33, q(7.6) \\
2.33, q(7.6)\end{array}$ & - & - & - & - & $2.46, \mathrm{~m}$ \\
\hline $12-\mathrm{CO}_{2} \mathrm{CH}_{2} \mathrm{CH}_{3}$ & $1.16, \mathrm{t}(7.7)$ & - & - & - & - & $1.18, \mathrm{t}(7.6)$ \\
\hline $13-\mathrm{OH}$ & - & d & - & - & - & - \\
\hline $20-\mathrm{OCOCH}_{3}$ & $2.03, \mathrm{~s}$ & $2.02, \mathrm{~s}$ & - & - & - & - \\
\hline $20-\mathrm{CO}_{2} \mathrm{CH}_{2} \mathrm{CH}_{3}$ & - & - & - & $2.31, q(7.7)$ & $2.46, \mathrm{~m}$ & $2.50, \mathrm{~m}$ \\
\hline 20- $\mathrm{CO}_{2} \mathrm{CH}_{2} \mathrm{CH}_{3}$ & & & & $2.31, \mathrm{q}(7.7)$ & $2.46, \mathrm{~m}$ & $2.45, \mathrm{~m}$ \\
\hline $2 \mathrm{O}-\mathrm{CO}_{2} \mathrm{CH}_{2} \mathrm{CH}_{3}$ & - & - & - & $1.13, \mathrm{t}(7.7)$ & $1.18, \mathrm{t}(7.7)$ & $1.12, \mathrm{t}(7.5)$ \\
\hline
\end{tabular}

${ }^{a}$ Chemical shifts $(\mathrm{ppm})$ referenced to $\mathrm{CHCl}_{3}\left(\delta_{\mathrm{H}} 7.26, \delta_{\mathrm{C}} 77.16\right) .{ }^{b}$ At $500 \mathrm{MHz} .{ }^{c}$ At $700 \mathrm{MHz} .{ }^{d}$ Not observed.

Table 4. ${ }^{13} \mathrm{C}$ NMR assignments for spongian-16-one analogues 6-11 ${ }^{a}$.

\begin{tabular}{|c|c|c|c|c|c|c|}
\hline \multirow{2}{*}{ Position } & \multicolumn{6}{|c|}{$\delta_{C}$, mult. } \\
\hline & $6^{c}$ & $7^{c}$ & $8^{b}$ & $9^{b}$ & $10^{c}$ & $11^{c}$ \\
\hline 1 & $35.1, \mathrm{CH}_{2}$ & $35.4, \mathrm{CH}_{2}$ & $39.9, \mathrm{CH}_{2}$ & $35.1, \mathrm{CH}_{2}$ & $33.8, \mathrm{CH}_{2}$ & $33.8, \mathrm{CH}_{2}$ \\
\hline 2 & $18.3, \mathrm{CH}_{2}$ & $18.5, \mathrm{CH}_{2}$ & $18.5, \mathrm{CH}_{2}$ & $18.4, \mathrm{CH}_{2}$ & $18.2, \mathrm{CH}_{2}$ & $18.2, \mathrm{CH}_{2}$ \\
\hline 3 & $41.5, \mathrm{CH}_{2}$ & $41.6, \mathrm{CH}_{2}$ & $42.1, \mathrm{CH}_{2}$ & $41.7, \mathrm{CH}_{2}$ & $41.3, \mathrm{CH}_{2}$ & $41.5, \mathrm{CH}_{2}$ \\
\hline 4 & $32.8, \mathrm{C}$ & $33.0, \mathrm{C}$ & $33.1, \mathrm{C}$ & $33.1, \mathrm{C}$ & $33.0, \mathrm{C}$ & $32.9, \mathrm{C}$ \\
\hline 5 & $57.1, \mathrm{CH}$ & $57.0, \mathrm{CH}$ & $56.8, \mathrm{CH}$ & $56.9, \mathrm{CH}$ & $58.0, \mathrm{CH}$ & $58.2, \mathrm{CH}$ \\
\hline 6 & $17.8, \mathrm{CH}_{2}$ & $17.9, \mathrm{CH}_{2}$ & $18.1, \mathrm{CH}_{2}$ & $17.9, \mathrm{CH}_{2}$ & 17.6, $\mathrm{CH}_{2}$ & $18.1, \mathrm{CH}_{2}$ \\
\hline 7 & $42.2, \mathrm{CH}_{2}$ & $42.8, \mathrm{CH}_{2}$ & $42.0, \mathrm{CH}_{2}$ & $42.2, \mathrm{CH}_{2}$ & $42.1, \mathrm{CH}_{2}$ & $41.9, \mathrm{CH}_{2}$ \\
\hline 8 & $35.6, \mathrm{C}$ & $36.3, \mathrm{C}$ & $35.5, \mathrm{C}$ & $36.0, \mathrm{C}$ & $35.1, \mathrm{C}$ & $33.2, \mathrm{C}$ \\
\hline 9 & $50.0, \mathrm{CH}$ & $56.7, \mathrm{CH}$ & $48.8, \mathrm{CH}$ & $49.0, \mathrm{CH}$ & $62.6, \mathrm{CH}$ & $64.2, \mathrm{CH}$ \\
\hline 10 & $39.8, \mathrm{C}$ & $40.4, \mathrm{C}$ & $36.1, \mathrm{C}$ & $40.2, \mathrm{C}$ & $41.2, \mathrm{C}$ & $40.7, \mathrm{C}$ \\
\hline 11 & $25.6, \mathrm{CH}_{2}$ & $19.4, \mathrm{CH}_{2}$ & $27.1, \mathrm{CH}_{2}$ & $29.2, \mathrm{CH}_{2}$ & $70.4, \mathrm{CH}$ & 67.7, $\mathrm{CH}$ \\
\hline 12 & $67.9, \mathrm{CH}$ & $28.1, \mathrm{CH}_{2}$ & $65.1, \mathrm{CH}$ & $64.9, \mathrm{CH}$ & $66.4, \mathrm{CH}$ & $69.5, \mathrm{CH}$ \\
\hline 13 & $43.1, \mathrm{CH}$ & $83.7, \mathrm{C}$ & $45.5, \mathrm{CH}$ & $45.6, \mathrm{CH}$ & $41.6, \mathrm{CH}$ & $38.7, \mathrm{CH}$ \\
\hline 14 & $49.1, \mathrm{CH}$ & $54.5, \mathrm{CH}$ & $48.3, \mathrm{CH}$ & $48.6, \mathrm{CH}$ & 47.6, CH & 47.7, $\mathrm{CH}$ \\
\hline 15 & 67.7, $\mathrm{CH}_{2}$ & $67.1, \mathrm{CH}_{2}$ & $67.9, \mathrm{CH}_{2}$ & $68.0, \mathrm{CH}_{2}$ & 67.7, $\mathrm{CH}_{2}$ & $66.9, \mathrm{CH}_{2}$ \\
\hline 16 & $174.9, \mathrm{C}$ & $173.6, \mathrm{C}$ & $176.3, \mathrm{C}$ & $176.4, \mathrm{C}$ & $180.3, \mathrm{C}$ & 178.2, C \\
\hline 17 & $15.3, \mathrm{CH}_{3}$ & $15.5, \mathrm{CH}_{3}$ & $15.4, \mathrm{CH}_{3}$ & $15.2, \mathrm{CH}_{3}$ & 17.7, $\mathrm{CH}_{3}$ & $17.6, \mathrm{CH}_{3}$ \\
\hline $18 \mathrm{eq}$ & $33.9, \mathrm{CH}_{3}$ & $33.9, \mathrm{CH}_{3}$ & $33.5, \mathrm{CH}_{3}$ & $33.9, \mathrm{CH}_{3}$ & $33.6, \mathrm{CH}_{3}$ & $33.6, \mathrm{CH}_{3}$ \\
\hline $19 a x$ & $22.1, \mathrm{CH}_{3}$ & $22.0, \mathrm{CH}_{3}$ & $21.6, \mathrm{CH}_{3}$ & $21.9, \mathrm{CH}_{3}$ & $21.9, \mathrm{CH}_{3}$ & $21.7, \mathrm{CH}_{3}$ \\
\hline 20 & $64.3, \mathrm{CH}_{2}$ & $64.3, \mathrm{CH}_{2}$ & $16.5, \mathrm{CH}_{3}$ & $64.5, \mathrm{CH}_{2}$ & $64.4, \mathrm{CH}_{2}$ & $64.7, \mathrm{CH}_{2}$ \\
\hline $11-\mathrm{CO}_{2} \mathrm{CH}_{2} \mathrm{CH}_{3}$ & - & - & - & - & $173.6, \mathrm{C}$ & - \\
\hline $11-\mathrm{CO}_{2} \mathrm{CH}_{2} \mathrm{CH}_{3}$ & - & - & - & - & $27.9, \mathrm{CH}_{2}$ & - \\
\hline $11-\mathrm{CO}_{2} \mathrm{CH}_{2} \mathrm{CH}_{3}$ & - & - & - & - & $9.2, \mathrm{CH}_{3}$ & - \\
\hline $12-\mathrm{CO}_{2} \mathrm{CH}_{2} \mathrm{CH}_{3}$ & 173.0, C & - & - & $174.5, \mathrm{C}$ & - & 172.6, C \\
\hline $12-\mathrm{CO}_{2} \mathrm{CH}_{2} \mathrm{CH}_{3}$ & 28.0, $\mathrm{CH}_{2}$ & - & - & $27.9, \mathrm{CH}_{2}$ & - & 27.7, $\mathrm{CH}_{2}$ \\
\hline $12-\mathrm{CO}_{2} \mathrm{CH}_{2} \mathrm{CH}_{3}$ & $9.4, \mathrm{CH}_{3}$ & - & - & $9.3, \mathrm{CH}_{3}$ & - & 9.1, $\mathrm{CH}_{3}$ \\
\hline $20-\mathrm{CO}_{2} \mathrm{CH}_{3}$ & $170.8, \mathrm{C}$ & $170.8, \mathrm{C}$ & - & - & - & - \\
\hline $20-\mathrm{CO}_{2} \mathrm{CH}_{3}$ & $21.2, \mathrm{CH}_{3}$ & $21.2, \mathrm{CH}_{3}$ & - & - & - & - \\
\hline $20-\mathrm{CO}_{2} \mathrm{CH}_{2} \mathrm{CH}_{3}$ & - & - & - & - & $174.2, \mathrm{C}$ & $175.5, \mathrm{C}$ \\
\hline $20-\mathrm{CO}_{2} \mathrm{CH}_{2} \mathrm{CH}_{3}$ & - & - & - & - & 27.6, $\mathrm{CH}_{2}$ & $27.4, \mathrm{CH}_{2}$ \\
\hline $20-\mathrm{CO}_{2} \mathrm{CH}_{2} \mathrm{CH}_{3}$ & - & - & - & - & $9.0, \mathrm{CH}_{3}$ & 9.4, $\mathrm{CH}_{3}$ \\
\hline
\end{tabular}


Metabolite 7, which was isolated as a colourless oil, exhibited an adduct ion at $\mathrm{m} / \mathrm{z}$ $401.2291[\mathrm{M}+\mathrm{Na}]^{+}$from HRESIMS, which corresponded to the same molecular formula as 5. The ${ }^{1} \mathrm{H}$ and ${ }^{13} \mathrm{C}$ NMR spectroscopic data again revealed an acetate group $\left(\delta_{\mathrm{H}} 2.02, \delta_{\mathrm{C}} 21.2\right.$, 170.8) while oxymethylene signals at $\delta_{\mathrm{H}} 4.55(\mathrm{~d}, J=13.1 \mathrm{~Hz})$ and $4.14(\mathrm{~d}, J=13.1 \mathrm{~Hz})$ were consistent with those of $\mathrm{H}_{2}-20$ in 6. HMBC correlations from the signals at $\delta_{\mathrm{H}} 4.55$ and 4.14 as well as from $\delta_{\mathrm{H}} 2.02$ to the carbon at $\delta_{\mathrm{C}} 170.8$ and to $\mathrm{C}-10\left(\delta_{\mathrm{C}} 40.4\right)$ confirmed the position of the acetate group at C-20. NOE correlations between H-20a/Me-19 and H-20b/Me-17 again placed the C-20 acetate on the same face as Me-17. The upfield chemical shift for $\mathrm{H}-14$ $\left(\delta_{\mathrm{H}} 1.94, \mathrm{dd}, J=5.6,7.8 \mathrm{~Hz}\right)$, together with $\mathrm{HMBC}$ correlations from signals at $\delta_{\mathrm{H}} 1.94(\mathrm{H}-14)$ and $4.13(\mathrm{H}-15 \mathrm{ax})$ to the quaternary carbon at $\delta_{\mathrm{C}} 83.7(\mathrm{C}-13)$, confirmed a hydroxy group at $\mathrm{C}-13$. The configuration at C-13 was not explored further, owing to the small quantity $(0.2 \mathrm{mg})$ of the sample, and was provisionally assigned by comparison with 1 and 3 . NOESY correlations between $\mathrm{H}-5 / \mathrm{H}-9$ and $\mathrm{H}-9 / \mathrm{H}-14$ confirmed the remaining stereochemistry. Compound 7 was assigned the systematic name (-)-20-acetoxy-13-hydroxyspongian-16-one.

Metabolite 8 was isolated as a colourless oil and displayed a sodiated ion at $\mathrm{m} / \mathrm{z}$ $343.2245[\mathrm{M}+\mathrm{Na}]^{+}$from HRESIMS for $\mathrm{C}_{20} \mathrm{H}_{32} \mathrm{O}_{3}$ suggesting an extra hydroxy group compared to spongian-16-one. gCOSY correlations from the oxygenated methine proton signal at $\delta_{\mathrm{H}} 4.52\left(\mathrm{H}-12\right.$, br s) to $\delta_{\mathrm{H}} 1.63\left(\mathrm{H}_{2}-11\right)$ and $2.66(\mathrm{H}-13)$ established the hydroxy group at the $\mathrm{C}-12$ position, further confirmed by HMBC correlations. NOESY correlations observed between H-5/H-9, H-9/H-14, and H-12/Me-17 confirmed the overall stereochemistry. Compound 8 was named as (-)-12 $\alpha$-hydroxyspongian-16-one.

Diterpene 9 was isolated as a colourless oil and produced an adduct ion at $\mathrm{m} / \mathrm{z} 415.2458$ $[\mathrm{M}+\mathrm{Na}]^{+}$from HRESIMS for $\mathrm{C}_{23} \mathrm{H}_{36} \mathrm{O}_{5}$. The ${ }^{1} \mathrm{H}$ NMR spectrum indicated a quartet $(2 \mathrm{H})$ at $\delta_{\mathrm{H}} 2.31$ and a triplet at $\delta_{\mathrm{H}} 1.13$, corresponding to propionate methylene and methyl signals. Oxymethylene signals at $\delta_{\mathrm{H}} 4.59(\mathrm{~d}, J=12.1 \mathrm{~Hz})$ and $4.17(\mathrm{~d}, J=12.1 \mathrm{~Hz})$ corresponded to those of $\mathrm{H}_{2}-20$ in 20-oxyspongian-16-one-propionate [30]. HMBC correlations from the signals at $\delta_{\mathrm{H}} 4.59$ and 4.17 , as well as from $\delta_{\mathrm{H}} 2.31(2 \mathrm{H})$ and 1.13 to the carbon at $\delta_{\mathrm{C}} 174.5$ and C-10 $\left(\delta_{\mathrm{C}} 40.2\right)$ confirmed the propionate group at C-20. The signals at $\delta_{\mathrm{H}} 4.49(\mathrm{H}-12$, br s) and $2.65(\mathrm{H}-13)$ were comparable to those in the ${ }^{1} \mathrm{H}$ NMR spectrum of 8 , positioning a hydroxy group at $\mathrm{C}-12$. NOE correlations between $\mathrm{Me}-17, \mathrm{H}-12$ and $\mathrm{H}_{2}-20$ positioned the propionate group on the same face and the $12-\mathrm{OH}$ on the opposite face to Me-17. The name of compound 9 was assigned as (-)-12 $\alpha$-hydroxy-20-oxyspongian-16-one-20-propionate.

Metabolite 10, a colourless oil, exhibited an adduct ion at $m / z 487.2668[\mathrm{M}+\mathrm{Na}]^{+}$ in the HRESIMS, corresponding to a molecular formula of $\mathrm{C}_{26} \mathrm{H}_{40} \mathrm{O}_{7}$, and 16 mass units larger than that of $12 \alpha, 20$-dioxyspongian-16-one-dipropionate [30]. The ${ }^{1} \mathrm{H}$ NMR spectrum revealed two multiplets at $\delta_{\mathrm{H}} 2.34(2 \mathrm{H})$ and $2.46(2 \mathrm{H})$ and two methyl triplets at $\delta_{\mathrm{H}} 1.15$ $(J=7.7 \mathrm{~Hz})$ and $1.18(J=7.7 \mathrm{~Hz})$. The addition of two ester carbonyls $\left(\delta_{C} 173.6\right.$ and 174.2$)$ and the lactone carbonyl $\left(\delta_{C}\right.$ 180.3) located six of the oxygen atoms, with the seventh oxygen atom inferred to be an additional hydroxy group. Oxymethylene signals at $\delta_{\mathrm{H}}$ $4.74(\mathrm{~d}, J=12.0 \mathrm{~Hz})$ and $3.96(\mathrm{dd}, J=1.9,12.0 \mathrm{~Hz})$ corresponded to those of $\mathrm{H}_{2}-20$ in 9 and 20-oxyspongian-16-one-propionate [30]. HMBC correlations from the signals at $\delta_{\mathrm{H}}$ 4.74 and 3.96 as well as from the signals at $\delta_{\mathrm{H}} 2.46(2 \mathrm{H})$ and 1.18 to the carbon at $\delta_{\mathrm{C}} 174.2$ and to $\mathrm{C}-10\left(\delta_{\mathrm{C}} 41.2\right)$ confirmed a propionate group at C-20. The multiplicity of the H-9 signal at $\delta_{\mathrm{H}} 1.35$ was a doublet rather than the doublet of doublets observed for 8. HMBC correlations from $\mathrm{H}-11\left(\delta_{\mathrm{H}}\right.$ 5.95) and 11-OCOCH $\mathrm{CH}_{3}\left(\delta_{\mathrm{H}} 2.34\right.$ and 1.15) to the propionate carbonyl at $\delta_{\mathrm{C}} 173.6$ located the second propionate group at C-11. gCOSY correlations from $\mathrm{H}-11$ and $\mathrm{H}-13\left(\delta_{\mathrm{H}} 2.84\right)$ to $\mathrm{H}-12\left(\delta_{\mathrm{H}} 2.79\right)$ confirmed the hydroxy group at $\mathrm{C}-12$. The $9.4 \mathrm{~Hz}$ coupling between $\mathrm{H}-12 \mathrm{ax}$ and $\mathrm{H}-13$ established a boat conformation for ring $\mathrm{C}$ [7]. NOESY correlations observed between H-5/H-9, H-9/H-14, H-20b/Me-17, and H-12/Me17 confirmed the overall stereochemistry. Compound $\mathbf{1 0}$ was named systematically as (-)-12 $\alpha$-hydroxy-11 $\beta, 20$-dioxyspongian-16-one-11 $\beta, 20$-dipropionate.

The spongian-16-one analogue $\mathbf{1 1}$ was isolated as a colourless oil and produced an adduct ion at $m / z 487.2667[\mathrm{M}+\mathrm{Na}]^{+}$, giving the same molecular formula as 10, implying two propionate groups and a hydroxy group. The ${ }^{1} \mathrm{H}$ and ${ }^{13} \mathrm{C}$ NMR spectroscopic data 
revealed signals for two propionate groups. Similar to 10 , two ester carbonyls $\left(\delta_{\mathrm{C}} 172.6\right.$ and 175.5) and a lactone carbonyl $\left(\delta_{C}\right.$ 178.2) were identified. HMBC correlations from the signals at $\delta_{\mathrm{H}} 4.61(\mathrm{~d}, J=12.2 \mathrm{~Hz})$ and $4.02(\mathrm{dd}, J=1.8,12.2 \mathrm{~Hz})$ as well as from $\delta_{\mathrm{H}} 2.50$, 2.45 and 1.12 to the carbon at $\delta_{C} 175.5$ and $C-10\left(\delta_{C} 40.7\right)$ confirmed a propionate group at C-20. HMBC correlations from the signal at $\delta_{\mathrm{H}} 5.54(\mathrm{H}-12, \mathrm{dd}, J=3.0,9.2 \mathrm{~Hz})$ to the signal at $\delta_{\mathrm{C}} 172.6$ located the second propionate group at C-12. Lastly, the occurrence of a signal at $\delta_{\mathrm{H}} 1.34(\mathrm{~d}, J=3.0 \mathrm{~Hz})$ for $\mathrm{H}-9$, together with gCOSY correlations from $\mathrm{H}-12$ and $\mathrm{H}-9$ to $\mathrm{H}-11\left(\delta_{\mathrm{H}} 4.46\right)$, established a hydroxy group at C-11. The $9.2 \mathrm{~Hz}$ coupling between $\mathrm{H}-12 \mathrm{ax}$ and $\mathrm{H}-13$ again established a boat conformation for ring $\mathrm{C}$ [7]. The NOESY correlations observed between H-5/H-9, H-9/H-14, H-20b/Me-17, and H-12/Me17 confirmed the overall stereochemistry. Compound 11 was named as (-)-11 $\beta$-hydroxy$12 \alpha, 20$-dioxyspongian-16-one-12 $\alpha, 20$-dipropionate.

\subsection{Anatomical Distribution of Metabolites}

Comparison of individual body parts by ${ }^{1} \mathrm{H}$ NMR spectroscopy, together with subsequent isolation work, revealed that new metabolites 1-5 were solely isolated from the mantle tissue of G. aureopurpureus. Likewise, new metabolites 6-11 were isolated only from the mantle tissue of Goniobranchus sp. 1. We also found that both species had more chemical diversity of metabolites in the mantle relative to the viscera. A full list of metabolites found in each body part is provided in the Supplementary Material. This pattern of anatomical distribution matches that of four Goniobranchus species that we previously studied (G. tinctorius, G. tasmaniensis, G. collingwoodi, and G. splendidus) [7,35]. These species may accumulate compounds in the mantle as they feed on a variety of sponge species with different chemistry. Compounds in the mantle are thought to be used for defensive purposes, and complex defensive mixtures may provide protection from a range of predators [10]. In contrast, we previously found two species (G. hunterae and G. verrieri) with the same metabolites in the mantle and viscera tissue, and one species (G. daphne) with fewer compounds in the mantle compared to the viscera [35].

\section{Conclusions}

In conclusion, the isolation work was conducted on two Goniobranchus species and afforded eleven new spongian diterpenes with oxidation at various positions, such as C-6, C-7, C-11, C-12, C-13, and/or C-20. The X-ray structure of 1 provided insight into the absolute configuration of the parent spongian-16-one [4,5]. Many of these highly oxygenated spongian diterpenes were only isolated from the mantle tissue, where they may play a role in deterring predators.

\section{Materials and Methods}

\subsection{General Experimental Procedure}

Specific rotations were measured at $23{ }^{\circ} \mathrm{C}$ on a Jasco P-2000 polarimeter for solutions in $\mathrm{CHCl}_{3}$ using a 1-millilitre cell (10-centimetre path length). NMR spectroscopic data were recorded on a Bruker Avance 500 spectrometer using a 5-millimetre SEI probe or a Bruker Avance DRX $700 \mathrm{MHz}$ spectrometer with a 5-millimetre TXI Zgrad probe for solutions in $\mathrm{CDCl}_{3}$ at $298 \mathrm{~K}$. Heteronuclear single quantum correlation (HSQC) and heteronuclear multiple bond correlation (HMBC) data were acquired using a ${ }^{1} J_{\mathrm{C}-\mathrm{H}}$ of $145 \mathrm{~Hz}$, while HMBC spectra were acquired using ${ }^{n} J_{C-H}$ of $8 \mathrm{~Hz}$. Positive and negative ion electrospray mass spectra were determined using either a Bruker Esquire HCT 3D ion trap instrument for low-resolution electrospray ionization mass spectrometry (LRESIMS) or a MicrOTOF-Q or an Orbitrap Elite instrument for high-resolution electrospray ionization mass spectrometry (HRESIMS) with MeOH as solvent. Normal-phase high-performance liquid chromatography (NP-HPLC) was undertaken using a Waters 515 pump connected to a Gilson 132 series refractive index detector with a Phenomenex Luna $(5 \mu \mathrm{m}, 10 \times 250 \mathrm{~mm})$ column, using isocratic elution conditions at flow rates between 1-2 mL/ min. Silica gel $60 \mathrm{G}$ and silica 
TLC plates $\mathrm{F}_{254}$ were purchased from Merck. Solvents were either distilled or were HPLC grade.

\subsection{Biological Material}

Six individuals of Goniobranchus aureopurpureus were collected from Nelson Bay (\#14691474), New South Wales in March 2016. Three individuals of Goniobranchus (Chromodoris) sp. 1 were collected from Mudjimba (\#1368 and \#1563) and Gneerings Reefs (\#1575) (Mooloolaba, Queensland) in October 2015 and October 2016. All collections were stored in individual containers at $-20{ }^{\circ} \mathrm{C}$ until dissection into mantle and gut prior to extraction.

\subsection{Extraction and Purification}

The mantle and viscera tissue of each specimen of G. aureopurpureus and G. sp 1 were extracted in acetone $(3 \times 2 \mathrm{~mL})$ and sonicated $(5 \mathrm{~min})$ separately. The extracts were reduced to aqueous suspensions, extracted with $\mathrm{Et}_{2} \mathrm{O}(3 \times 3 \mathrm{~mL})$, dried over anhydrous $\mathrm{Na}_{2} \mathrm{SO}_{4}$, and concentrated under $\mathrm{N}_{2}$ to give an orange oil (mantle tissue) or a green oil (viscera). The ${ }^{1} \mathrm{H}$ NMR profile of the mantle and viscera extracts were compared between the specimens of each species and showed similar chemistry; for G. aureopurpureus (specimens \#1469-1474) the mantle extracts were combined $(51.9 \mathrm{mg}$ ) and the viscera extracts combined $(56.1 \mathrm{mg})$ to produce two extracts. For G. sp 1 (specimens \#1563, 1368 and 1575), the mantle extracts were combined $(96.8 \mathrm{mg})$, as were the viscera extracts $(71.2 \mathrm{mg})$. The extracts were further separated by NP-flash column chromatography with a stepwise solvent gradient from $100 \%$ hexanes to $100 \% \mathrm{MeOH}$.

Mantle fractions of G. aureopurpureus were further separated by NP-HPLC (25-30\% EtOAc in hexanes) to yield 15-desacetoxy-12-acetoxydendrillolide A (0.4 mg), spongian-16one $(2.5 \mathrm{mg})$, macfarlandin $\mathrm{E}(1.8 \mathrm{mg})$, aplyviolene $(1.6 \mathrm{mg}), 7 \alpha$-acetoxyspongian-16-one $(0.6 \mathrm{mg})$, polyrhaphin B $(0.1 \mathrm{mg})$, secoshahamin $(0.1 \mathrm{mg})$, shahamin C $(0.1 \mathrm{mg}), 7 \alpha$-acetoxy$6 \beta$-hydroxyspongian-16-one (5: $0.22 \mathrm{mg}), 13$-acetoxy-20-hydroxy- $7 \alpha$-oxyspongian-16-one$7 \alpha$-(2-methyl)-butanoate (1: $1.2 \mathrm{mg}), 6 \beta$-hydroxy-7 $\alpha$-oxyspongian-16-one-7 $\alpha$-(2-methyl)butanoate (3: $0.06 \mathrm{mg}), 20$-acetoxy-6 $\beta$-hydroxy-7 $\alpha$-oxyspongian-16-one-7 $\alpha$-(2-methyl)butanoate (2: $0.07 \mathrm{mg})$, and 13-acetoxy-20-hydroxy-7 $\alpha$-oxyspongian-16-one-7 $\alpha$-(3-methyl)butanoate (4: $0.8 \mathrm{mg})$. Viscera fractions of G. aureopurpureus were further separated by NPHPLC (25-30\% EtOAc in hexanes) to yield luffarin- $X(0.22 \mathrm{mg})$, spongian-16-one $(0.43 \mathrm{mg})$ macfarlandin E (0.46 mg), polyrhaphin B $(0.1 \mathrm{mg})$, secoshahamin $(0.12 \mathrm{mg})$, polyrhaphin A (0.32 mg), 12-desacetoxypolyrhaphin A (0.14 mg), 15,16-diacetoxyshahamin B (0.14 mg), aplyviolene $(0.79 \mathrm{mg})$, and $7 \alpha$-acetoxyspongian-16-one ( $0.44 \mathrm{mg})$.

The NP-flash column chromatography mantle fractions of Goniobranchus sp 1 were separated by NP-HPLC ( $30 \%$ EtOAc in hexanes) to provide isoagatholactone $(0.5 \mathrm{mg}), 12 \alpha$ acetoxyspongian-16-one $(0.23 \mathrm{mg})$, 20-acetoxyspongian-16-one (7.94 mg), 20-oxyspongian-16one-propionate $(0.35 \mathrm{mg}), 12 \alpha, 20$-diacetoxyspongian-16-one $(0.43 \mathrm{mg}), 12 \alpha, 20$-dioxyspongian16-one-dipropionate $(1.30 \mathrm{mg}), 12 \alpha$-acetoxy-20-oxyspongian-16-one-20-propionate $(0.28 \mathrm{mg})$, 20-acetoxy-12 $\alpha$-oxyspongian-16-one-12 $\alpha$-propionate (6: $0.21 \mathrm{mg})$, and 20-acetoxy-13hydroxyspongian-16-one (7: $0.17 \mathrm{mg})$. Mantle fractions eluting from DCM/EtOAc 4:1 and 1:1 were separated by NP-HPLC (30\% EtOAc in hexanes) to yield 12-hydroxyspongian16-one (8: $0.08 \mathrm{mg}), 12$-hydroxy-20-oxyspongian-16-one-20-propionate (9: $0.97 \mathrm{mg}), 12-$ hydroxy-11,20-dioxyspongian-16-one-11,20-dipropionate (10: $0.17 \mathrm{mg})$, and 11-hydroxy12,20-dioxyspongian-16-one-12,20-dipropionate (11: $0.11 \mathrm{mg})$. Viscera fractions eluting from hexanes/DCM (1:1 and 1:4), 100\% DCM and DCM/EtOAc 4:1 were combined and separated by NP-HPLC (30\% EtOAc in hexanes), providing isoagatholactone $(0.16 \mathrm{mg})$, spongian-16-one ( $2.59 \mathrm{mg}), 7 \alpha$-acetoxyspongian-16-one $(0.57 \mathrm{mg}), 12 \alpha$-acetoxyspongian- 16 one (1.01 mg), 20-acetoxyspongian-16-one $(0.30 \mathrm{mg})$, and $12 \alpha, 20$-diacetoxyspongian- 16 -one (0.83 mg).

(-)-13-Acetoxy-20-hydroxy-7 $\alpha$-oxyspongian-16-one-7 $\alpha$-(2-methyl)-butanoate (1): colourless oil (1.2 mg); $[\alpha]_{D}^{21}-12$ (c 0.12, $\left.\mathrm{CHCl}_{3}\right) ;{ }^{1} \mathrm{H} \mathrm{NMR}$ and ${ }^{13} \mathrm{C} \mathrm{NMR}\left(\mathrm{CDCl}_{3}, 700 \mathrm{MHz}\right)$, Tables 1 and 2; HRESIMS $m / z 501.2829$ [M + Na] ${ }^{+}$(calculated for $\mathrm{C}_{27} \mathrm{H}_{42} \mathrm{NaO}_{7}$, 501.2823). 
(-)-20-Acetoxy-6 $\beta$-hydroxy-7 $\alpha$-oxyspongian-16-one-7 $\alpha$-(2-methyl)-butanoate (2): colourless oil (0.07 mg); $[\alpha]_{D}^{21}-71\left(c 0.007, \mathrm{CHCl}_{3}\right) ;{ }^{1} \mathrm{H} \mathrm{NMR}$ and ${ }^{13} \mathrm{C} \mathrm{NMR}\left(\mathrm{CDCl}_{3}, 700 \mathrm{MHz}\right)$, Tables 1 and 2; HRESIMS $m / z$ 501.2824 [M + Na] ${ }^{+}$(calculated for $\mathrm{C}_{27} \mathrm{H}_{42} \mathrm{NaO}_{7}, 501.2823$ ).

(-)-6 $\beta$-Hydroxy-7 $\alpha$-oxyspongian-16-one-7 $\alpha$-(2-methyl)-butanoate (3): colourless oil (0.06 mg); $[\alpha]_{D}^{21}-167$ (c 0.006, $\left.\mathrm{CHCl}_{3}\right) ;{ }^{1} \mathrm{H} \mathrm{NMR}$ and ${ }^{13} \mathrm{C} \mathrm{NMR}\left(\mathrm{CDCl}_{3}, 700 \mathrm{MHz}\right)$, Tables 1 and 2; HRESIMS $m / z 443.2779[\mathrm{M}+\mathrm{Na}]^{+}$(calculated for $\mathrm{C}_{25} \mathrm{H}_{40} \mathrm{NaO}_{5}, 443.2768$ ).

(-)-13-Acetoxy-20-hydroxy-7 $\alpha$-oxyspongian-16-one-7 $\alpha$-(3-methyl)-butanoate (4): colourless oil (0.8 mg); $[\alpha]_{D}^{21}-19\left(c 0.08, \mathrm{CHCl}_{3}\right) ;{ }^{1} \mathrm{H} \mathrm{NMR}$ and ${ }^{13} \mathrm{C} \mathrm{NMR}\left(\mathrm{CDCl}_{3}, 700 \mathrm{MHz}\right)$, Tables 1 and 2; HRESIMS $m / z$ 501.2831 [M + Na $]^{+}$(calculated for $\mathrm{C}_{27} \mathrm{H}_{42} \mathrm{NaO}_{7}, 501.2823$ ).

(-)-7 $\alpha$-Acetoxy-6 $\beta$-hydroxyspongian-16-one (5): colourless oil $(0.22 \mathrm{mg}) ;[\alpha]_{D}^{21}-65(c$ $\left.0.022, \mathrm{CHCl}_{3}\right) ;{ }^{1} \mathrm{H} \mathrm{NMR}$ and ${ }^{13} \mathrm{C} \mathrm{NMR}\left(\mathrm{CDCl}_{3}, 700 \mathrm{MHz}\right)$, Tables 1 and 2; HRESIMS $\mathrm{m} / z$ $401.2293[\mathrm{M}+\mathrm{Na}]^{+}$(calculated for $\mathrm{C}_{22} \mathrm{H}_{34} \mathrm{NaO}_{5}, 401.2298$ ).

(-)-20-Acetoxy-12 $\alpha$-oxyspongian-16-one-12 $\alpha$-propionate (6): colourless oil (0.21 mg); $[\alpha]_{D}^{21}-29\left(\right.$ c $\left.0.021, \mathrm{CHCl}_{3}\right) ;{ }^{1} \mathrm{H} \mathrm{NMR}$ and ${ }^{13} \mathrm{C} \mathrm{NMR}\left(\mathrm{CDCl}_{3}, 700 \mathrm{MHz}\right)$, Tables 3 and 4; HRESIMS $m / z$ 457.2566 [M + Na] ${ }^{+}$(calculated for $\mathrm{C}_{25} \mathrm{H}_{38} \mathrm{NaO}_{6}, 457.2561$ ).

(-)-20-Acetoxy-13-hydroxyspongian-16-one (7): colourless oil $(0.17 \mathrm{mg}) ;[\alpha]_{D}^{21}-22(c$ 0.017, $\left.\mathrm{CHCl}_{3}\right) ;{ }^{1} \mathrm{H}$ NMR and ${ }^{13} \mathrm{C} \mathrm{NMR}\left(\mathrm{CDCl}_{3}, 700 \mathrm{MHz}\right)$, Tables 3 and 4; HRESIMS $\mathrm{m} / z$ 401.2291 [M + Na] ${ }^{+}$(calculated for $\mathrm{C}_{22} \mathrm{H}_{34} \mathrm{NaO}_{5}, 401.2298$ ).

(-)-12-Hydroxyspongian-16-one (8): colourless oil $(0.08 \mathrm{mg}) ;[\alpha]_{D}^{21}-58$ (c $\left.0.01, \mathrm{CHCl}_{3}\right)$;

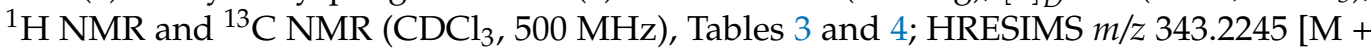
$\mathrm{Na}]^{+}$(calculated for $\mathrm{C}_{20} \mathrm{H}_{32} \mathrm{NaO}_{3}, 343.2244$ ).

(-)-12-Hydroxy-20-oxyspongian-16-one-20-propionate (9): colourless oil (0.97 mg); $[\alpha]_{D}^{21}-7\left(c\right.$ 0.097, $\left.\mathrm{CHCl}_{3}\right) ;{ }^{1} \mathrm{H} \mathrm{NMR}$ and ${ }^{13} \mathrm{C} \mathrm{NMR}\left(\mathrm{CDCl}_{3}, 500 \mathrm{MHz}\right)$, Tables 3 and 4; HRESIMS $m / z 415.2458[\mathrm{M}+\mathrm{Na}]^{+}$(calculated for $\mathrm{C}_{23} \mathrm{H}_{36} \mathrm{NaO}_{5}, 415.2455$ ).

(-)-12-Hydroxy-11,20-dioxyspongian-16-one-11,20-dipropionate (10): colourless oil (0.17 mg); $[\alpha]_{D}^{21}-35$ (c 0.017, $\left.\mathrm{CHCl}_{3}\right) ;{ }^{1} \mathrm{H}$ NMR and $\left.{ }^{13} \mathrm{C} \mathrm{NMR} \mathrm{(} \mathrm{CDCl}_{3}, 700 \mathrm{MHz}\right)$, Tables 3 and 4; HRESIMS $m / z$ 487.2668 [M + Na] ${ }^{+}$(calculatedfor $\mathrm{C}_{26} \mathrm{H}_{40} \mathrm{NaO}_{7}$, 487.2666).

(-)-11-Hydroxy-12,20-dioxyspongian-16-one-12,20-dipropionate (11): colourless oil (0.11 mg); $[\alpha]_{D}^{21}-64\left(c 0.011, \mathrm{CHCl}_{3}\right) ;{ }^{1} \mathrm{H} \mathrm{NMR}$ and ${ }^{13} \mathrm{C} \mathrm{NMR}\left(\mathrm{CDCl}_{3}, 700 \mathrm{MHz}\right)$, Tables 3 and 4; HRESIMS $m / z$ 487.2667 [M + Na] ${ }^{+}$(calculated for $\mathrm{C}_{26} \mathrm{H}_{40} \mathrm{NaO}_{7}, 487.2666$ ).

\subsection{X-ray Crystallographic Structure Determination}

Full details of X-ray crystallography methods and data are available in the Supplementary Materials.

Crystallographic data for 1: $\mathrm{C}_{27} \mathrm{H}_{42} \mathrm{O}_{7}(M=478.60 \mathrm{~g} / \mathrm{mol})$ : orthorhombic, space group $\mathrm{P} 2{ }_{1} 2{ }_{1} 2{ }_{1}$ (no. 19), $a=7.9081(2) \AA, b=11.0710(3) \AA, c=30.2192(8) \AA, V=2645.73(12) \AA^{3}$, $\mathrm{Z}=4, T=100.01(10) \mathrm{K}, \mu(\mathrm{MoK} \alpha)=0.085 \mathrm{~mm}^{-1}$, Dcalc $=1.202 \mathrm{~g} / \mathrm{cm}^{3}$, 34647 reflections measured $\left(4.562^{\circ} \leq 2 \Theta \leq 56.56^{\circ}\right), 6562$ unique $\left(R_{\text {int }}=0.0495, R_{\text {sigma }}=0.0347\right)$ which were used in all calculations. The final $R_{1}$ was $0.0416(\mathrm{I}>2 \sigma(\mathrm{I}))$ and $w R_{2}$ was 0.1191 (all data).

Crystallographic data for 4: $\mathrm{C}_{27} \mathrm{H}_{42} \mathrm{O}_{7}(M=478.60 \mathrm{~g} / \mathrm{mol})$ : orthorhombic, space group $\mathrm{P} 2{ }_{1} 2_{1} 2_{1}$ (no. 19), $a=7.9438(3) \AA, b=11.2958(8) \AA, c=28.897(2) \AA, V=2593.0(3) \AA^{3}, Z=4, T$ $=99.99(10) \mathrm{K}, \mu(\mathrm{Mo} \mathrm{K} \alpha)=0.087 \mathrm{~mm}^{-1}$, Dcalc $=1.226 \mathrm{~g} / \mathrm{cm}^{3}, 24810$ reflections measured $\left(4.578^{\circ} \leq 2 \Theta \leq 50.246^{\circ}\right), 4642$ unique $\left(R_{\text {int }}=0.0727, R_{\text {sigma }}=0.0429\right)$ which were used in all calculations. The final $R_{1}$ was $0.0804(\mathrm{I}>2 \sigma(\mathrm{I}))$ and $w R_{2}$ was 0.2256 (all data).

Supplementary Materials: The following are available online at https:/ /www.mdpi.com/article/10 .3390/md19120680/s1. Figure S1: An image of G. aureopurpureus and Giniobranchus sp. 1; Figure S2: X-ray crystallography image of diterpene 4; Figures S3-S56: NMR and 2D NMR spectra of diterpenes 1-11 $\left({ }^{1} \mathrm{H}, \mathrm{COSY}, \mathrm{HSQC}, \mathrm{HMBC}\right.$, and NOESY). Tables S1 and S2 and Figures S57-S62: Anatomical distribution of metabolites.

Author Contributions: Conceptualization, L.C.F. and M.J.G.; methodology, L.C.F. and J.K.C.; formal analysis, L.C.F., J.K.C. and M.J.G.; investigation, L.C.F., J.K.C. and M.J.G.; resources, K.L.C. and M.J.G.; data curation, L.C.F.; writing—original draft preparation, L.C.F., K.L.C. and M.J.G.; writing—review 
and editing, L.C.F., K.L.C., J.K.C. and M.J.G.; supervision, K.L.C. and M.J.G.; project administration, M.J.G. All authors have read and agreed to the published version of the manuscript.

Funding: This research was supported by the School of Chemistry and Molecular Sciences, The University of Queensland.

Institutional Review Board Statement: Not applicable.

Data Availability Statement: Raw NMR data files are available from the authors on request. All other data is contained within this manuscript.

Acknowledgments: The assistance of T. Le, G. Pierens (NMR), and Peter Josh (MS) is acknowledged. Specimens were collected under a NSW Department of Primary Industries Scientific Collection Permit (\# P16/0052-1.0) and QLD General Fisheries Permits (\#161624 and \#183990).

Conflicts of Interest: The authors declare no conflict of interest.

\section{References}

1. Gonzalez, M.A. Spongiane diterpenoids. Curr. Bioact. Compd. 2007, 3, 1-36. [CrossRef]

2. Keyzers, R.A.; Northcote, P.T.; Davies-Coleman, M.T. Spongian diterpenoids from marine sponges. Nat. Prod. Rep. 2006, 23, 321-334. [CrossRef] [PubMed]

3. Cimino, G.; De Rosa, D.; De Stefano, S.; Minale, L. Isoagatholactone, a diterpene of a new structural type from the sponge Spongia officinalis. Tetrahedron 1974, 30, 645-649. [CrossRef]

4. Kernan, M.R.; Cambie, R.C.; Bergquist, P.R. Chemistry of Sponges, IX. New diterpenes from the marine sponge Dictyodendrilla cavernosa. J. Nat. Prod. 1990, 53, 724-727. [CrossRef]

5. Hambley, T.W.; Poiner, A.; Taylor, W.C. The constituents of marine sponges. V. The isolation from Chelonaplysilla violacea (Dendroceratida) of aplyviolene and other diterpenes, and the determination of the crystal structure of aplyviolene. Aust. J. Chem. 1990, 43, 1861-1870. [CrossRef]

6. Miyamoto, T.; Sakamoto, K.; Arao, K.; Komori, T.; Higuchi, R.; Sasaki, T. Dorisenones, cytotoxic spongian diterpenoids, from the nudibranch Chromodoris obsoleta. Tetrahedron 1996, 52, 8187-8198. [CrossRef]

7. Forster, L.C.; Winters, A.E.; Cheney, K.L.; Dewapriya, P.; Capon, R.J.; Garson, M.J. Spongian-16-one diterpenes and their anatomical distribution in the Australian nudibranch Goniobranchus collingwoodi. J. Nat. Prod. 2017, 80, 670-675. [CrossRef]

8. Forster, L.C.; Pierens, G.K.; Clegg, J.K.; Garson, M.J. Dynamic NMR and computational studies inform the conformational description of dendrillane terpenes from the nudibranch Goniobranchus coi. J. Nat. Prod. 2020, 83, 714-719. [CrossRef]

9. Forster, L.C.; Pierens, G.K.; Garson, M.J. Elucidation of relative and absolute configurations of highly rearranged diterpenoids and evidence for a putative biosynthetic intermediate from the Australian nudibranch Goniobranchus geometricus. J. Nat. Prod. 2019, 82, 449-455. [CrossRef]

10. Winters, A.E.; White, A.M.; Cheney, K.L.; Garson, M.J. Geographic variation in diterpene-based secondary metabolites and level of defence in an aposematic nudibranch, Goniobranchus splendidus. J. Mollusc. Stud. 2019, 85, 133-142. [CrossRef]

11. Dewi, A.S.; Pierens, G.K.; Cheney, K.L.; Blanchfield, J.T.; Garson, M.J. Chromolactol, an oxygenated diterpene from the Indo-Pacific nudibranch Goniobranchus coi: Spectroscopic and computational studies. Aust. J. Chem. 2018, 71, 798-803. [CrossRef]

12. Winters, A.E.; Wilson, N.G.; van den Berg, C.P.; How, M.J.; Endler, J.A.; Marshall, N.J.; White, A.M.; Garson, M.J.; Cheney, K.L. Toxicity and taste: Unequal chemical defences in a mimicry ring. Proc. Roy. Soc. B Biol. Sci. 2018, 285, 20180457. [CrossRef]

13. Forster, L.C.; White, A.M.; Cheney, K.L.; Garson, M.J. Oxygenated terpenes from the Indo-Pacific nudibranchs Goniobranchus splendidus and Goniobranchus collingwoodi. Nat. Prod. Commun. 2018, 13, 299-302. [CrossRef]

14. Winters, A.E.; Green, N.F.; Wilson, N.G.; How, M.J.; Garson, M.J.; Marshall, N.J.; Cheney, K.L. Stabilizing selection on individual pattern elements of aposematic signals. Proc. Roy. Soc. B Biol. Sci. 2017, 284, 20170926. [CrossRef] [PubMed]

15. Forster, L.C.; Pierens, G.K.; White, A.M.; Cheney, K.L.; Dewapriya, P.; Capon, R.J.; Garson, M.J. Cytotoxic spiroepoxide lactone and its putative biosynthetic precursor from Goniobranchus Splendidus. ACS Omega 2017, 2, 2672-2677. [CrossRef] [PubMed]

16. White, A.M.; Pierens, G.K.; Forster, L.C.; Winters, A.E.; Cheney, K.L.; Garson, M.J. Rearranged diterpenes and norditerpenes from three Australian Goniobranchus mollusks. J. Nat. Prod. 2016, 79, 477-483. [CrossRef] [PubMed]

17. White, A.M.; Dewi, A.S.; Cheney, K.L.; Winters, A.E.; Blanchfield, J.T.; Garson, M.J. Oxygenated diterpenes from the Indo-Pacific nudibranchs Goniobranchus splendidus and Ardeadoris egretta. Nat. Prod. Commun. 2016, 11. [CrossRef]

18. Hirayama, Y.; Katavic, P.L.; White, A.M.; Pierens, G.K.; Lambert, L.K.; Winters, A.E.; Kigoshi, H.; Kita, M.; Garson, M.J. New cytotoxic norditerpenes from the Australian nudibranchs Goniobranchus Splendidus and Goniobranchus Daphne. Aust. J. Chem. 2016, 69, 136-144. [CrossRef]

19. Mudianta, I.W.; White, A.M.; Garson, M.J. Oxygenated terpenes from Indo-Pacific nudibranchs: Scalarane sesterterpenes from Glossodoris hikuerensis and 12-acetoxy dendrillolide A from Goniobranchus albonares. Nat. Prod. Commun. 2015, 10, 865-868. [CrossRef] [PubMed]

20. Cobb, G.T.; Willan, R.C. Undersea Jewels: A Colour Guide to Nudibranchs; Australian Govt. Dept. of the Environment and Heritage: Canberra, Australia, 2006. 
21. Johnson, R.F.; Gosliner, T.M. Traditional taxonomic groupings mask evolutionary history: A molecular phylogeny and new classification of the chromodorid nudibranchs. PLoS ONE 2012, 7, e33479. [CrossRef]

22. Molinski, T.F.; Faulkner, D.J.; He, C.H.; Van Duyne, G.D.; Clardy, J. Three new rearranged spongian diterpenes from Chromodoris macfarlandi: Reappraisal of the structures of dendrillolides A and B. J. Org. Chem. 1986, 51, 4564-4567. [CrossRef]

23. Hambley, T.W.; Poiner, A.; Taylor, W.C. Diterpene metabolites of the marine sponge Chelonaplysilla violacea: Aplyviolene and aplyviolacene. Tetrahedron Lett. 1986, 27, 3281-3282. [CrossRef]

24. Bobzin, S.C.; Faulkner, D.J. Diterpenes from the marine sponge Aplysilla polyrhaphis and the dorid nudibranch Chromodoris norrisi. J. Org. Chem. 1989, 54, 3902-3907. [CrossRef]

25. Carmely, S.; Cojocaru, M.; Loya, Y.; Kashman, Y. Ten new rearranged spongian diterpenes from two Dysidea species. J. Org. Chem. 1988, 53, 4801-4807. [CrossRef]

26. Uddin, M.H.; Hossain, M.K.; Nigar, M.; Roy, M.C.; Tanaka, J. New cytotoxic spongian-class rearranged diterpenes from a marine sponge. Chem. Nat. Comp. 2012, 48, 412-415. [CrossRef]

27. Butler, M.S.; Capon, R.J. The luffarins (A-Z), novel terpenes from an Australian marine sponge, Luffariella geometrica. Aust. J. Chem. 1992, 45, 1705-1743. [CrossRef]

28. Karuso, P.; Taylor, W.C. The constituents of marine sponges. II. The isolation from Aplysilla rosea (dendroceratida) of (5R* $7 \mathrm{~S}^{*}$, $\left.8 \mathrm{R}^{*}, 9 \mathrm{~S}^{*}, 10 \mathrm{R}^{*}, 13 \mathrm{~S}^{*}, 14 \mathrm{~S}^{*}, 15 \mathrm{~S}^{*}\right)-15,17$-epoxy-17-hydroxy-16-oxospongian-7-yl butyrate (aplyroseol-1) and related diterpenes (aplyroseol-2 to aplyroseol-6). Aust. J. Chem. 1986, 39, 1629-1641.

29. Bobzin, S.C.; Faulkner, D.J. Novel rearranged spongian diterpenes from the Palauan sponge Dendrilla sp.: Reassessment of the structures of dendrillolide A and dendrillolide B. J. Org. Chem. 1989, 54, 5727-5731. [CrossRef]

30. Katavic, P.L.; Jumaryatno, P.; Hooper, J.N.A.; Blanchfield, J.T.; Garson, M.J. Oxygenated terpenoids from the Australian sponges Coscinoderma matthewsi and Dysidea sp. and the nudibranch Chromodoris albopunctata. Aust. J. Chem. 2012, 65, 531-538. [CrossRef]

31. Rettinger, K.; Karl, V.; Schmarr, H.G.; Dettmar, F.; Hener, U.; Mosandl, A. Chirospecific analysis of 2-alkyl-branched alcohols, acids, and esters: Chirality evaluation of 2-methylbutanoates from apples and pineapples. Phytochem. Anal. 1991, 2, 184-188. [CrossRef]

32. Farrugia, L. ORTEP-3 for Windows-A version of ORTEP-III with a graphical user interface (GUI). J. Appl. Cryst. 1997, 30 Pt 1, 565. [CrossRef]

33. Suciati; Lambert, L.K.; Garson, M.J. Structures and anatomical distribution of oxygenated diterpenes in the Australian nudibranch Chromodoris reticulata. Aust. J. Chem. 2011, 64, 757-765. [CrossRef]

34. Schroeder, F.C.; Gronquist, M. Extending the scope of NMR spectroscopy with microcoil probes. Angew. Chem. Int. Ed. 2006, 45, 7122-7131. [CrossRef] [PubMed]

35. Winters, A.E.; White, A.M.; Dewi, A.S.; Mudianta, I.W.; Wilson, N.G.; Forster, L.C.; Garson, M.J.; Cheney, K.L. Distribution of defensive metabolites in nudibranch molluscs. J. Chem. Ecol. 2018, 44, 384-396. [CrossRef] [PubMed] 